\title{
Revision of the South African endemic bee genus Redivivoides Michener, 1981 (Hymenoptera: Apoidea: Melittidae)
}

\author{
Michael KUHLMANN \\ Department of Life Sciences, The Natural History Museum, \\ Cromwell Road, London, SW7 5BD, United Kingdom. \\ E-mail: m.kuhlmann@nhm.ac.uk \\ urn:Isid:zoobank.org:author:B99AE0ED-FA89-4DFE-A658-1C8DF37F9FAB
}

\begin{abstract}
The South African endemic bee genus Redivivoides Michener, 1981 is revised and redefined. The genus comprises seven species, six of which are described here as new: Redivivoides capensis sp. nov. $+\hat{\jmath}, R$. eardleyi sp. nov. + , $R$. kamieskroonensis sp. nov. + , $R$. karooensis sp. nov. $\overbrace{}^{\lambda}$, $R$. namaquaensis sp. nov. $+\hat{O}$ and $R$. variabilis sp. nov. $+\hat{O}$. A key to species is provided.
\end{abstract}

Key words. Redivivoides, bees, South Africa, new species, taxonomy.

Kuhlmann M. 2012. Revision of the South African endemic bee genus Redivivoides Michener, 1981 (Hymenoptera: Apoidea: Melittidae). European Journal of Taxonomy 34:1-34. http://dx.doi.org/10.5852/ejt.2012.34

\section{Introduction}

The bee genus Redivivoides was described by Michener (1981) based on a single species, $R$. simulans Michener, 1981, collected in the winter rainfall region of western South Africa. Two other species were only known from a few female specimens and remained undescribed. Since then much more material of this genus has become available representing now a total of seven species, six of which are described here as new. The morphological diversity of the newly described species required a re-evaluation of the characters defining Redivivoides as a genus.

Redivivoides belongs to the subfamily Melittinae Schenck, 1860 and the tribe Melittini Schenck, 1860 that also includes the genera Melitta Kirby, 1802 and Rediviva Friese, 1911 (Michez et al. 2009). Michener (1981) suggested that Redivivoides is the sister-group of Rediviva and the close relationship of both genera was later confirmed by phylogenetic studies (Danforth et al. 2006; Michez et al. 2009). However, unlike Redivivoides, the females of Rediviva collect floral oil that is mixed with pollen for nest provisioning from a range of oil-producing flowers, with Diascia (Scrophulariaceae) as their principal floral host (Whitehead \& Steiner 2001; Pauw 2006; Whitehead et al. 2008). In several Rediviva species the forelegs are elongate, sometimes longer than the entire body, and the lengths of floral spurs and bee legs in some cases show co-variation at the population level, suggesting co-evolution (Steiner \& Whitehead 1990, 1991). Because Melittidae are the most basal bees (Danforth et al. 2006), Redivivoides and Rediviva are a key group for understanding the evolution of oil-collecting in bees (Michez et al. 2009) and they might also help to understand the origin of the unusual bee diversity in the Greater Cape Floristic Region (Kuhlmann 2009). 
The goal of this publication is to describe the six new species and to provide a key for species identification to facilitate further research on this fascinating group of bees. Based on the descriptions and the analysis of the morphology of the new species, Redivivoides is redefined as a genus and its relationship to its putative sister group, the oil-collecting Rediviva bees, is briefly discussed.

\section{Material and methods}

Terminology for the description of species is based on Michener (2007) for general morphology. Puncture density is expressed as the relationship between puncture diameter (d) and the space between them (i), such as $\mathrm{i}=1.5 \mathrm{~d}$ or $\mathrm{i}<\mathrm{d}$. The following abbreviations were used for morphological structures:

$\mathrm{T}=$ metasomal tergum

$\mathrm{S} \quad=$ metasomal sternum

Body length was measured from the vertex to the apex of the body.

Acronyms for collections (after Arnett et al. 1993) from which specimens were borrowed or deposited, are as follows:

AMGS = Albany Museum, Grahamstown, South Africa

CUIC $=$ Cornell University Collection, Ithaca, USA

EMUS = Entomological Museum, Utah State University, USA

LPCT $=$ Laurence Packer collection, Toronto, Canada

$\mathrm{SAMC}=$ South African Museum, Cape Town, South Africa

SANC $=$ South African National Collection of Insects, Pretoria, South Africa

$\mathrm{RCMK}=$ research collection of Michael Kuhlmann, London, UK

Nomenclature of plant names follows Germishuizen \& Meyer (2003). If not given on the labels, coordinates of collecting sites are given in square brackets and places were identified using Microsoft Encarta ${ }^{\circledR}$ World Atlas (version 10, 2001). Geographical coordinates are given in the following format: degree.minutes.seconds. Distribution maps were generated using DMAP V7.2 (www.dmap.co.uk).

Scanning electron microscopy (SEM) was carried out using a Leo 1455VP. The backscattered electron images were taken under low vacuum (variable pressure) of uncoated specimens. In this mode electronpoor organic material appears darker than electron-rich material (e.g. soil dust particles) consisting of heavier chemical elements.

\section{Results}

Classis Hexapoda Blainville, 1816

Ordo Hymenoptera Linnaeus, 1758

Superfamilia Apoidea Latreille, 1802

Epifamilia Anthophila Latreille, 1804

Familia Melittidae Schenck, 1860

Subfamilia Melittinae Schenck, 1860

Tribus Melittini Schenck, 1860

Genus Redivivoides Michener, 1981 


\section{Redivivoides Michener, 1981}

Redivivoides Michener, 1981: 42-44, figs 80, $82-84$ (p. 43), 97 (p. 48).

Type species: Redivivoides simulans Michener, 1981, by original designation.

The diagnosis of Redivivoides given by Michener (1981) was solely based on R. simulans, which was the only known species of the genus at that time. However, in some respects $R$. simulans is an exception within the genus so a redefinition of Redivivoides is required in the light of the six new species described in this paper (see discussion).

A comprehensive phylogenetic analysis of Redivivoides and related genera is in preparation to investigate the intra-generic relationships, so for convenience the species are here listed in alphabetical order.

\section{Redivivoides capensis sp. nov.}

Figs 1E-F, 2, 3, 4

urn:1sid:zoobank.org:act:60C46E16-6E85-43BE-AA18-A7977B6CF097

\section{Diagnosis}

Males and females of $R$. capensis sp. nov. can be separated from other Redivivoides species by their extensively and brightly red metasomal terga (Figs 2D, 3C) in combination with an impunctate and densely shagreened scutum (Figs 2C, 3B).
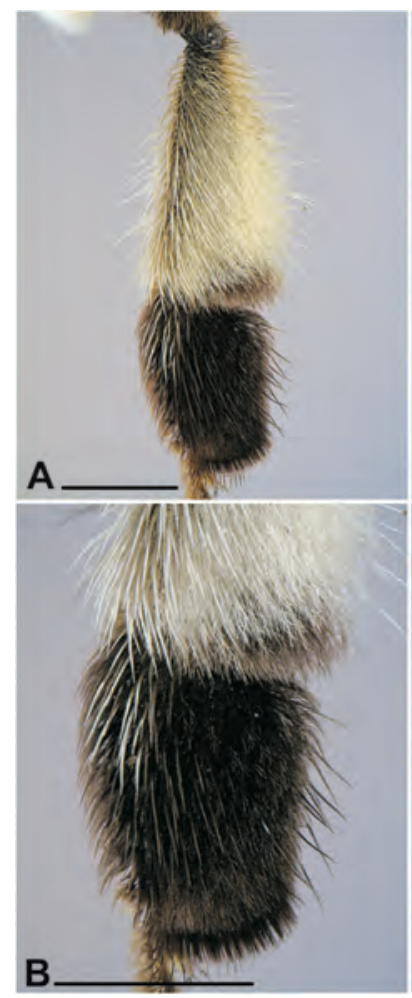
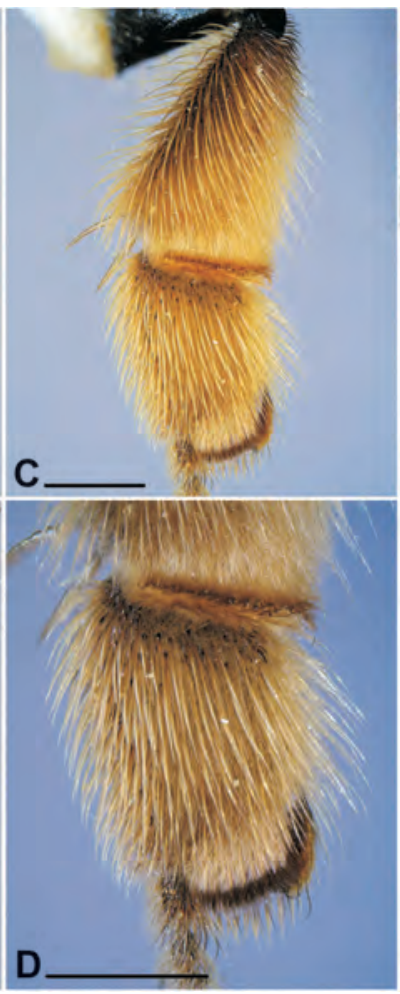
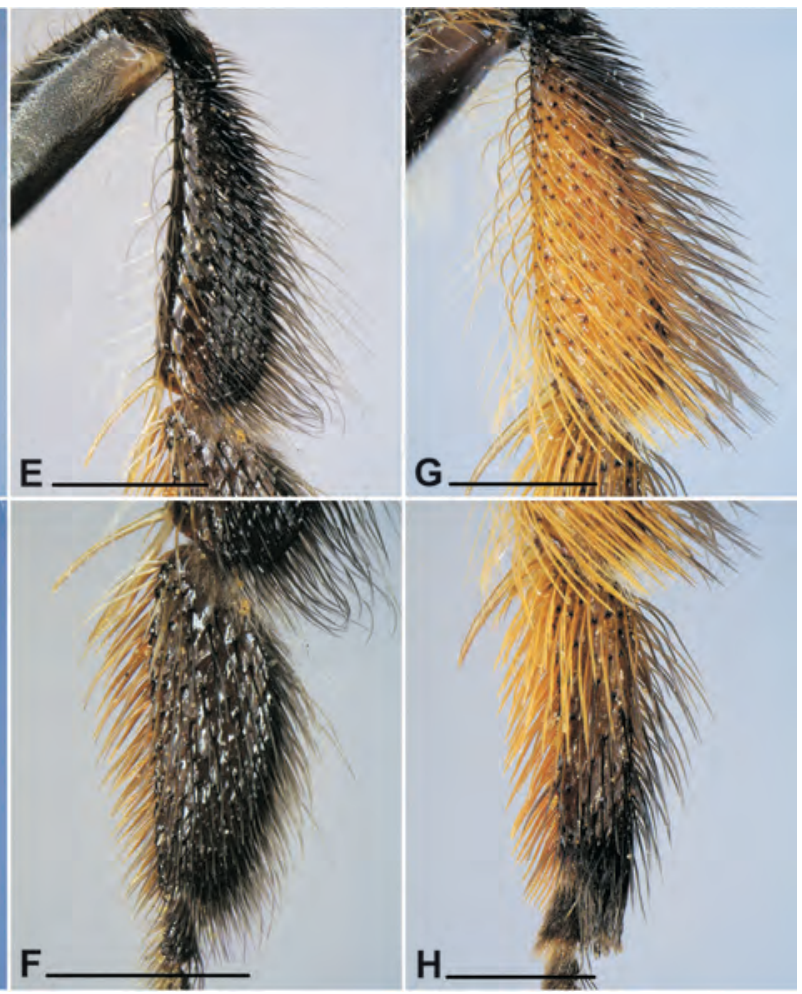

Fig. 1. - A-B. Macropis europaea Warncke, 1973, ․ A. Hind leg, dorsal view. B. Hind basitarsus, dorsal view. - C-D. Rediviva intermixta (Cockerell, 1934), . . C. Hind leg, dorsal view. D. Hind basitarsus, dorsal view. - E-F. Redivivoides capensis sp. nov., ㅇ. E. Hind tibia, dorsal view. F. Hind basitarsus, dorsal view. - G-H. Melitta arrogans (Smith, 1879), ․ . G. Hind tibia, dorsal view. H. Hind basitarsus, dorsal view. Scale bar: $1 \mathrm{~mm}$. 


\section{Etymology}

Named after the Cape of Good Hope ("the Cape").

Type material (18 specimens)

\section{Holotype}

ㅇ, M. Kuhlmann leg. 15 Aug. 2010 / Redivivoides spec. 2, M. Kuhlmann det. 2011 (SAMC). SOUTH AFRICA: Farm Papkuilsfontein, 20 km S Nieuwoudtville, Fynbos, 31³3’16” S, 1908’31” E, 680 m.

\section{Paratypes}

SOUTH AFRICA: 4 + $q$ same date as Holotype (RCMK); 1 , N N. Cape, Fynbos, 2 km W Nieuwoudtville, near Grasberg [3121'05” S, 1905'49” E], 742 m, 23 Aug. 2003, K. Timmermann (RCMK); 1 ㅇ, N.

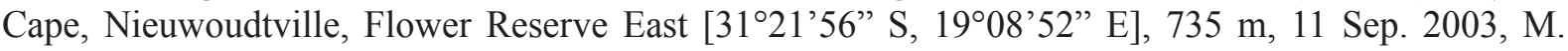

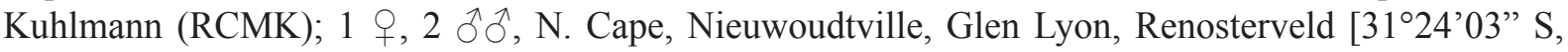

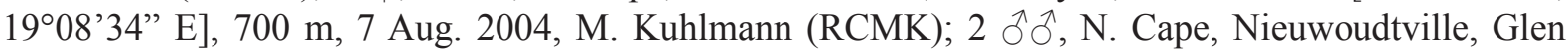

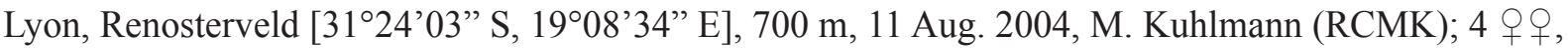
20 km S Nieuwoudtville, Farm Papkuilsfontein, Fynbos [31'33’16” S, 1908’31” E], 680 m, 27 Aug. 2010, M. Kuhlmann (SANC, RCMK); 1 \&, van Rhynsdorp, Cape [313'ㅅ S, $18^{\circ} 44^{\prime}$ E], 1929, Dr. Brauns (SAMC); 1 ㅇ, Clanwilliam, Ramskop [32¹0’ S, 1853’ E], 24 Jul. 1985, V.B. Whitehead (SAMC).
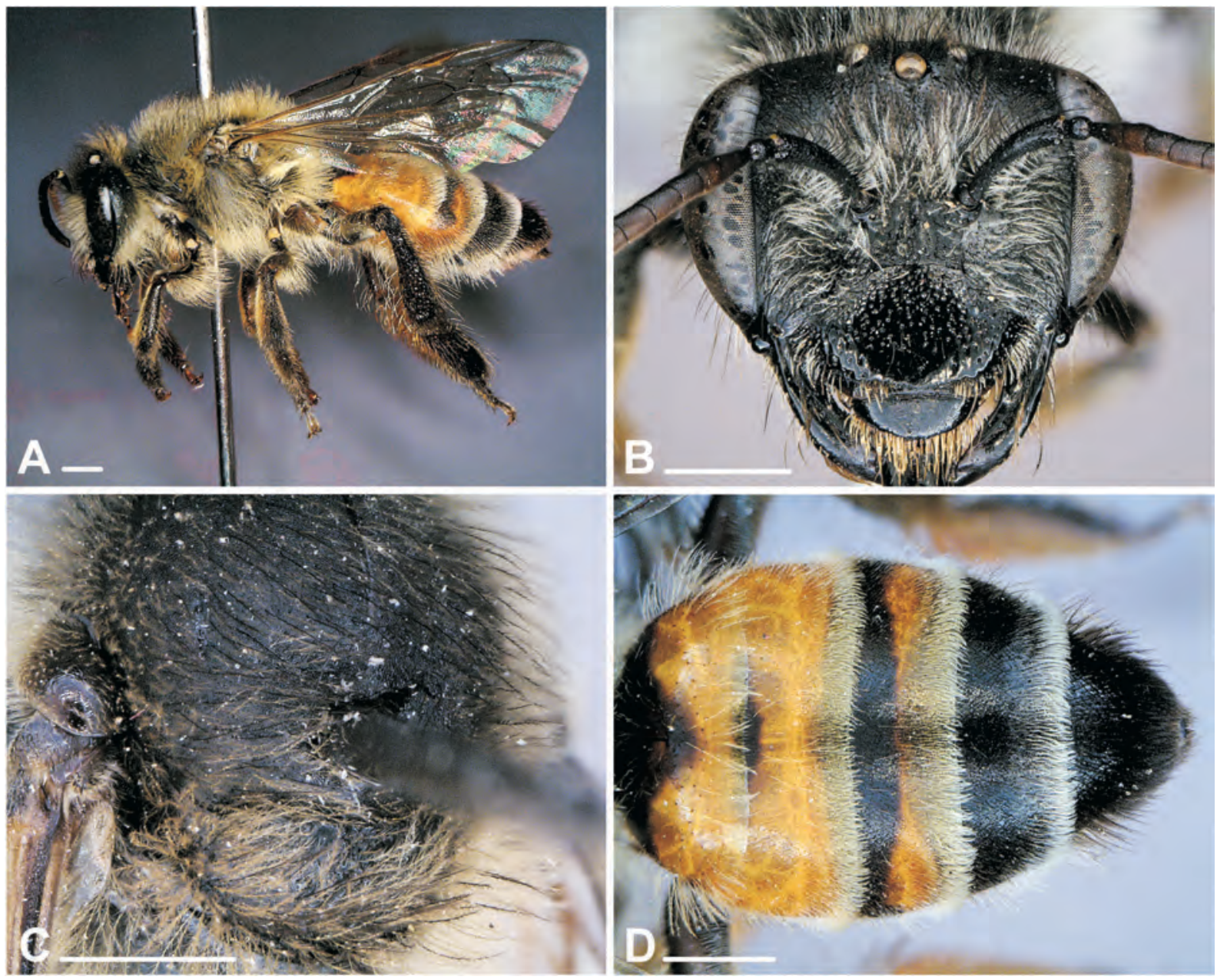

Fig. 2. Redivivoides capensis sp. nov., + . A. Lateral view. B. Head. C. Scutum and scutellum. D. Metasoma (dorsal view). Scale bar: $1 \mathrm{~mm}$. 

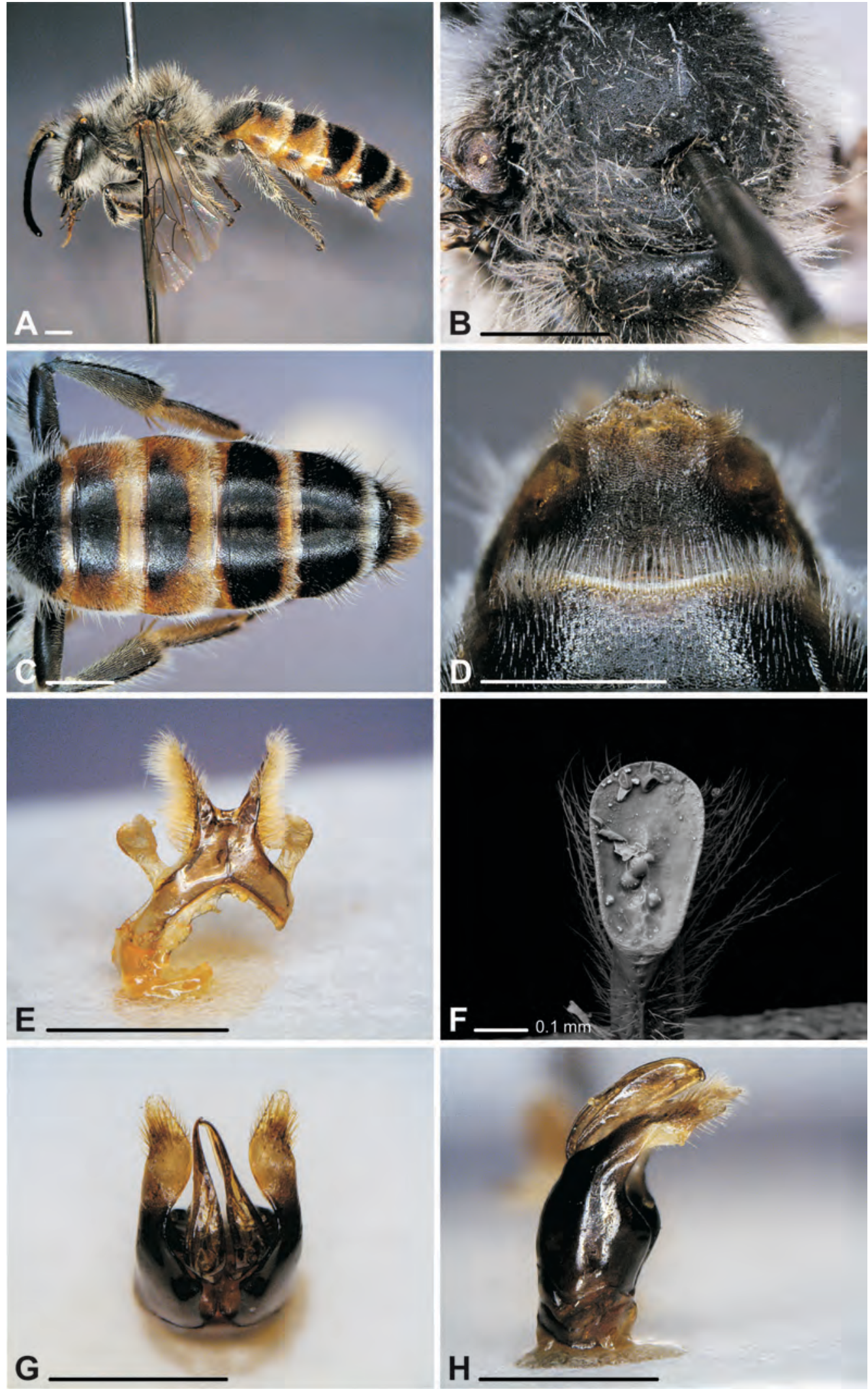

Fig. 3. Redivivoides capensis sp. nov., ${ }^{\lambda}$. A. Lateral view. B. Scutum and scutellum. C. Metasoma (dorsal view). D. S6 (ventral view). E. S7 (dorsal view). F. S8, apical end (backscattered electron image). G. Genitalia (dorsal view). H. Genitalia (lateral view). Scale bar: $1 \mathrm{~mm}$. 


\section{Description}

Female

BODY LENGTH. 9.0-10.5 mm.

HEAD. Head slightly wider than long. Integument black except tips of mandible partly dark reddishbrown. Face sparsely covered with long, whitish-grey to brown, erect hairs intermixed with black hairs especially along the inner eye margins and on vertex (Fig. 2B). Clypeus mostly flat, apically almost impunctate; medially covered with medium-sized punctures that become gradually smaller and denser towards the lateral and upper margins; surface between punctures shiny (Fig. 2B). Malar area medially narrow, almost linear. Antenna black, ventrally orange to reddish-brown.

Mesosoma. Integument black. Mesoscutum impunctate, finely shagreened and matt (Fig. 2C). Mesoscutum, scutellum, metanotum, mesepisternum and propodeum covered with long yellowishbrown erect hairs, on the disc of mesoscutum some black hairs intermixed.

WINGS. Yellowish-brown; wing venation dark brown.

LEGS. Integument black to dark reddish-brown. Vestiture of femora whitish-yellow, on tibiae and tarsi dark brown to black, scopae dark brown, ventrally hairs white to greyish-yellow.

Metasoma. Integument black, except T1 to a variable extent apically red, T2 red with a black spot anterior-medially, T3 apically with a red margin (Fig. 2D). T1 completely and T2 on disc sparsely covered with a few long erect yellowish-white hairs; T3 - T4 covered with short yellow to black hairs; apical tergal hair band missing on T1, on T2 - T4 broadly white (Fig. 2A, D). Prepygidial fimbria dorsally black, laterally partly white, pygidial fimbria black. Terga impunctate, finely shagreened with a silky shine (Fig. 2D).

\section{Male}

BODY LENGTH. 8.5-10.0 mm.

HEAD. Head slightly wider than long. Integument black except tip of mandible partly dark reddishbrown. Face sparsely covered with long, whitish-grey to brown, erect hairs intermixed with black hairs especially along the inner eye margins and on vertex. Clypeus mostly flat, apically almost impunctate; medially covered with medium-sized punctures that become gradually smaller and denser towards the lateral and upper margins; surface between punctures shiny. Malar area medially narrow, almost linear. Antenna black, ventrally reddish-brown.

Mesosoma. Integument black. Mesoscutum impunctate, finely shagreened and matt (Fig. 3B). Mesoscutum, scutellum, metanotum, mesepisternum and propodeum covered with long white to yellowish-grey erect hairs, on the scutellum black hairs intermixed (Fig. 3A).

WINGS. Slightly yellowish-brown; wing venation brown.

LEGS. Integument black, tibiae and tarsi partly dark red-brown. Vestiture whitish.

Metasoma. Integument black, except T1 to a variable extend apically red, T2 red with a black spot anterior-medially, T3 either like T2 or in some specimens only apically with a red margin, T4 in some males with red basal and apical margins (Fig. 3C). T1 completely and T2 - T3 on disc sparsely covered with a few long erect yellowish-white hairs; T4 - T6 covered with short black hairs; apical tergal hair band missing on T1, on T2 - T5 narrow and sparsely white (Fig. 3C). Terga impunctate, finely shagreened with a silky shine (Fig. 3C). 
Terminalia. Genitalia (Fig. 3G-H), S6 (Fig. 3D), S7 (Fig. 3E) and terminal plate of S8 (Fig. 3F) as illustrated.

\section{Distribution}

This species is only known from a few localities from Clanwilliam to the Nieuwoudtville area (Fig. 4).

\section{Floral hosts}

All specimens collected on the farms Papkuilsfontein and Glen Lyon were collected on Polygalaceae: Nylandtia scoparia.

\section{Seasonal activity}

July - September.

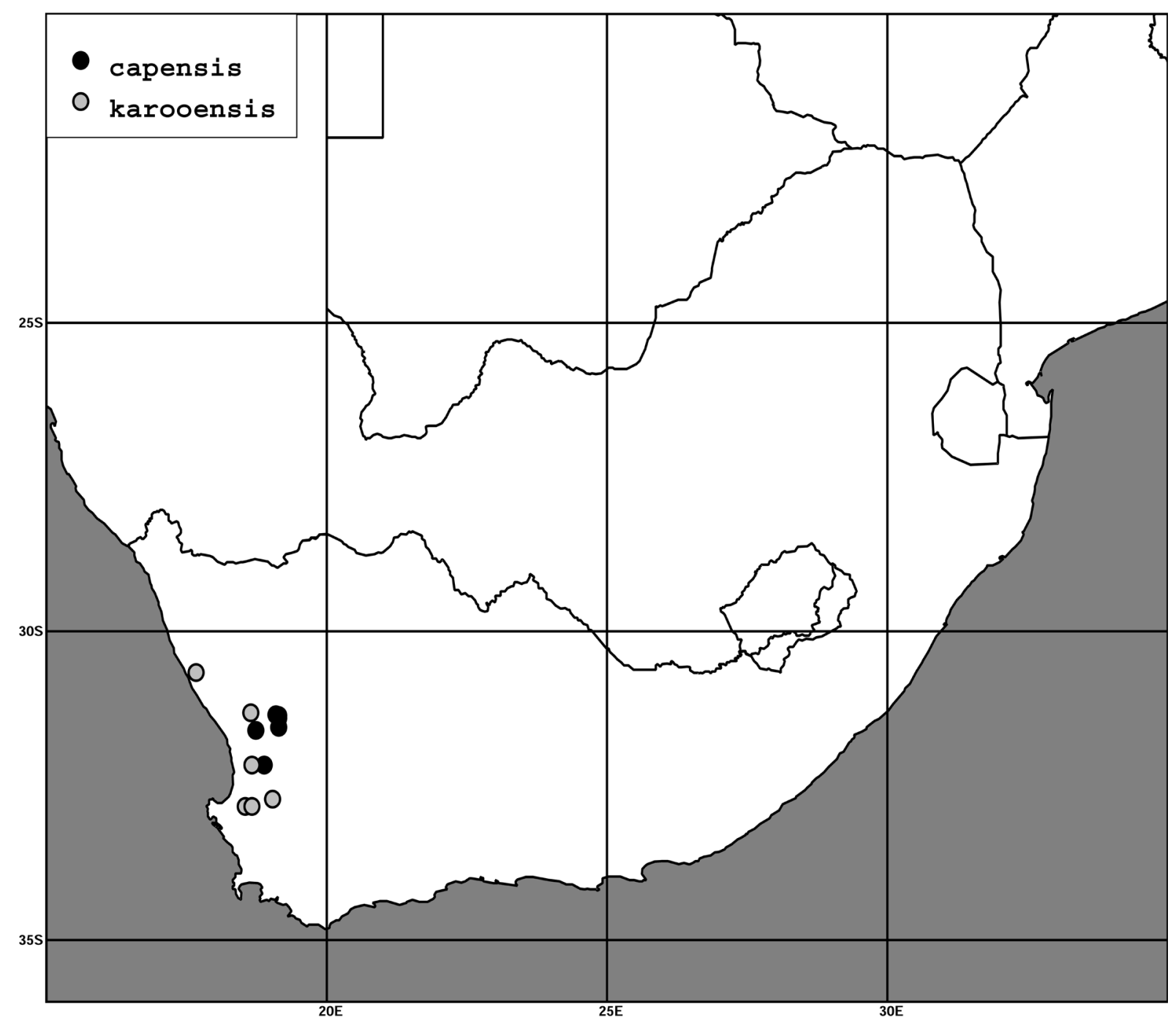

Fig. 4. Distribution of Redivivoides capensis sp. nov. and R. karooensis sp. nov. in South Africa. 


\section{Redivivoides eardleyi sp. nov. \\ Figs 5, 9 \\ urn:1sid:zoobank.org:act:543F31E2-5A26-4D78-A07A-674CA7997F19}

\section{Diagnosis}

Females of $R$. eardleyi sp. nov. can be separated from other Redivivoides species by a combination of the following characters: metasomal terga black to brown, T2 sparsely punctate with minute punctures and surface between punctures smooth and shiny, white apical tergal hair bands present (Fig. 5D), prepygidial and pygidial fimbria dark brown to black (Fig. 5D). The male is unknown.

\section{Etymology}

Named after Connal D. Eardley, Pretoria, who collected this species and to honour his outstanding contribution to African bee taxonomy.

\section{Type material (3 specimens)}

\section{Holotype}

ㅇ, 13 Sep. 2011, C. Eardley (SANC). SOUTH AFRICA: N. Cape, 6 km E Pofadder, 2906’26" S, $19^{\circ} 27^{\prime} 13^{\prime \prime} \mathrm{E}$.
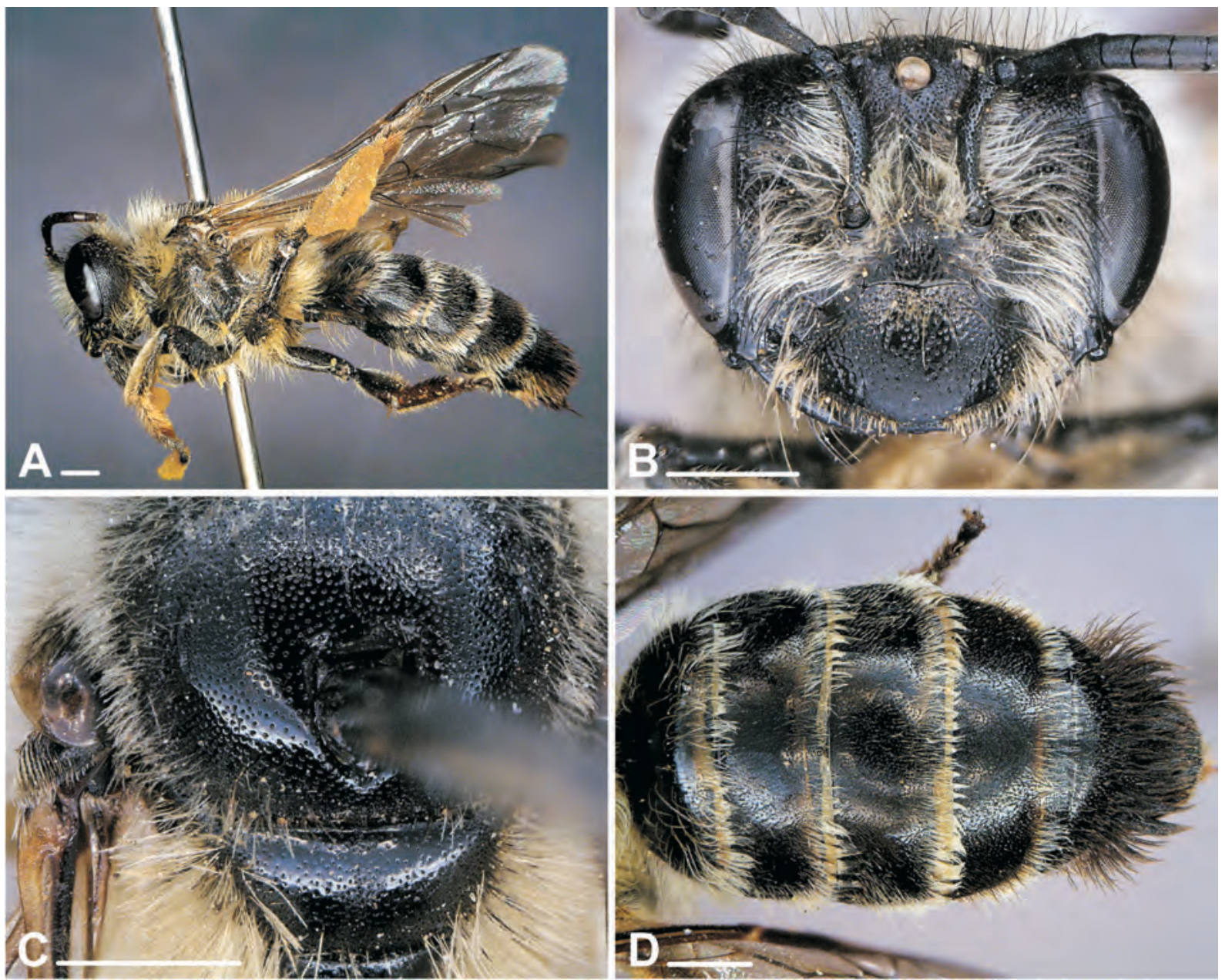

Fig. 5. Redivivoides eardleyi sp. nov., ․ A. Lateral view. B. Head. C. Scutum and scutellum. D. Metasoma (dorsal view). Scale bar: $1 \mathrm{~mm}$. 
Paratypes

SOUTH AFRICA: 1 q, same date as holotype (RCMK); 1 ㅇ, N. Cape, 21.6 km E Springbok [29³4' S, 1804’ E], 1006 m, 13 Sep. 2011, L. Packer (LPCT).

\section{Description}

Female

BODY LENGTH. $11.0 \mathrm{~mm}$.

HeAD. Head wider than long. Integument black. Face sparsely covered with long, whitish-grey, erect hairs, along the inner eye margins and on vertex intermixed with black hairs (Fig. 5B). Clypeus convex in profile, apically impunctate; medially covered with fine punctures that become gradually smaller and denser towards the clypeal margins; surface between punctures smooth and shiny (Fig. 5B). Malar area medially narrow, almost linear. Antenna black.

Mesosoma. Integument black. Mesoscutal disc between punctures smooth and shiny; disc densely $(\mathrm{i}=0.5-1.0 \mathrm{~d})$ and finely punctate (Fig. 5C). Mesoscutum, scutellum, metanotum, mesepisternum and propodeum covered with long yellowish-white erect hairs, on the disc of mesoscutum intermixed with black hairs.

WINGS. Yellowish-brown; wing venation reddish brown.

LEGS. Integument black. Vestiture whitish to brown, scopae yellowish to dark brown.

Metasoma. Integument black, apical margins of T2 - T4 narrowly reddish-brown (Fig. 5D). T1 with a few long erect whitish hairs; discs of T2 - T4 sparsely covered with very short erect white to dark brown hairs; apical tergal hair bands on T1 - T4 broad and white; prepygidial and pygidial fimbriae black (Fig. 5A, D). T1 almost impunctate, polished and shiny, T2 - T4 shiny, with very fine, superficial and sparse punctation that becomes progressively denser on apical tergae (Fig. 5D).

Male

Unknown.

\section{Distribution}

There is only a single record of this species from the Karoo in the summer rainfall area (Fig. 9).

\section{Floral hosts}

Unknown.

\section{Seasonal activity}

September.

Redivivoides kamieskroonensis sp. nov.

Figs 6, 9

urn:1sid:zoobank.org:act:C65B0CFE-D36A-4C57-BE42-7009CE0F357D

\section{Diagnosis}

Females of R. kamieskroonensis sp. nov. can be separated from other Redivivoides species by their extensively and brightly red metasomal terga (Fig. 6D) in combination with the head that is distinctly wider than long (Fig. 6B). Unlike other species the propodeal triangle is weakly shagreened. The male is unknown. 


\section{Etymology}

Named after the town Kamieskroon in NW South Africa, in the vicinity of which this species was discovered.

Type material (2 specimens)

\section{Holotype}

ㅇ, 16-17 Sep. 2001, C. Eardley / Redivivoides sp. 3, det. C.D. Eardley 2008 / (blue label): SANC-Pretoria, Database No: HYMA 08832. SOUTH AFRICA: N Cape, Dassiefontein Farm, 14 km E Kamieskroon, $30^{\circ} 09^{\prime} \mathrm{S}, 17^{\circ} 59^{\prime} \mathrm{E}$.

\section{Paratype}

SOUTH AFRICA: 1 q, NCP, Dassiefontein Farm, 14 road km E Kamieskroon [3009'31" S, 1759’96” E], 760 m, 16-17 Sep. 2001 (CUIC).

\section{Description}

\section{Female}

BODY LENGTH. $12.0 \mathrm{~mm}$.
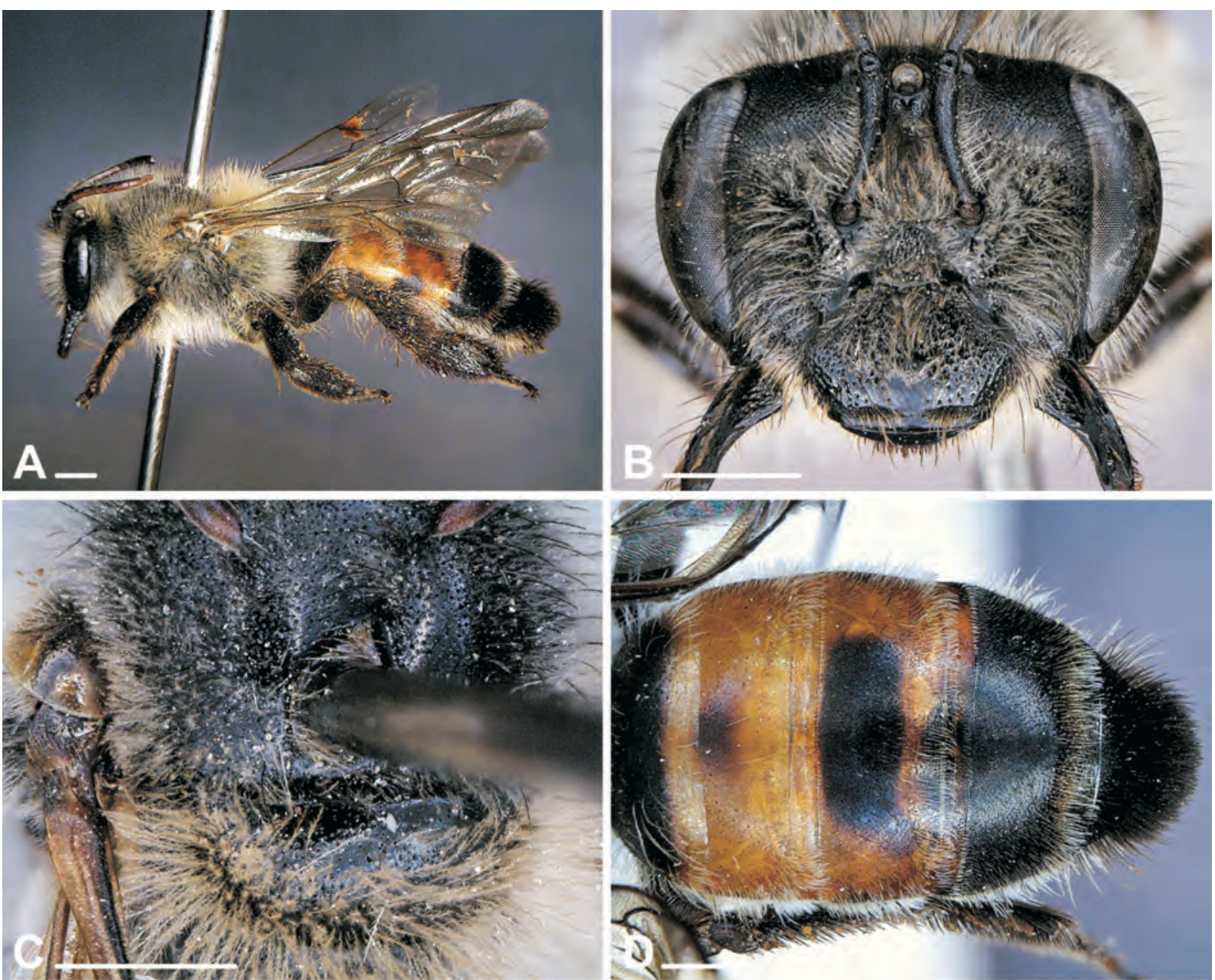

Fig. 6. Redivivoides kamieskroonensis sp. nov., ․ A. Lateral view. B. Head. C. Scutum and scutellum. D. Metasoma (dorsal view). Scale bar: $1 \mathrm{~mm}$. 
HeAD. Head much wider than long. Integument black except tips of mandible partly dark reddishbrown. Face sparsely covered with long, whitish-grey to brown, erect hairs intermixed with black hairs (Fig. 6B). Clypeus almost flat, slightly convex in profile in the lower part and slightly concave in the upper part, apico-medially and apical margin impunctate; clypeus otherwise densely (i $\leq \mathrm{d})$ covered with small punctures that become gradually smaller and denser towards the clypeal margins; surface between punctures shiny (Fig. 6B). Malar area medially about $1 / 4$ to $1 / 5$ as long as width of mandible base. Antenna black, ventrally reddish-brown.

Mesosoma. Integument black. Mesoscutal disc between punctures smooth and shiny; disc densely $(\mathrm{i}=0.5-1.0 \mathrm{~d}$ ) and finely punctate (Fig. 6C). Mesoscutum, scutellum, metanotum, mesepisternum and propodeum covered with long yellowish to whitish-grey erect hairs, on the disc of mesoscutum intermixed with black hairs.

WINGS. Yellowish-brown; wing venation dark reddish brown.

LeGs. Integument black, partly dark red-brown. Vestiture dark brown, scopae blackish-brown (Fig. 6A).

Metasoma. Integument mostly black, red are the apical part of T1, all of T2 except for a small black spot anterior-medially, T3 except for a large black spot in the same position and apical margin of T4 (Fig. 6D). T1 and T2 on disc with long erect yellowish-white hairs; T3 - T4 covered with mostly blackish and very short erect hairs; apical tergal hair bands on $\mathrm{T} 1$ - T4 medially broad, consisting of short sparse white hairs; prepygidial and pygidial fimbriae black (Fig. 6A, D). Terga impunctate, finely shagreened with a silky shine (Fig. 6D).

\section{Male \\ Unknown.}

\section{Distribution}

This species is only known from a single locality near Kamieskroon (Fig. 9).

\section{Floral hosts}

Unknown.

\section{Seasonal activity}

September.

Redivivoides karooensis sp. nov.

Figs 4, 7, 8

urn:lsid:zoobank.org:act:00C81E1F-78C5-406D-8132-0CC6ABD24EB9

\section{Diagnosis}

Females of $R$. karooensis sp. nov. can be separated from other Redivivoides species by a combination of the following characters: metasomal terga black to brown, T2 densely punctate with large punctures and surface between punctures smooth and shiny, white apical tergal hair bands present (Fig. 7D), prepygidial and pygidial fimbria dark brown to black (Fig. 7D). These characters also apply to males (Fig. 8C) but the genitalia and S6 - S8 (Fig. 8D-H) should be checked to avoid potential confusion with the unknown male of $R$. eardleyi.

\section{Etymology}

Named after the Karoo, the arid region in western and central South Africa where this species was found. 
Type material (22 specimens)

\section{Holotype}

+, 9 Sep. 1994, V.B. Whitehead / Phyllopodium heterophyllum / SAM-HYM-B009461“ (SAMC). SOUTH AFRICA: W. Cape, Sauer, Suurfontein, 3218DC, $18^{\circ} 40^{\prime}$ E, 3250’ S.

\section{Paratypes}

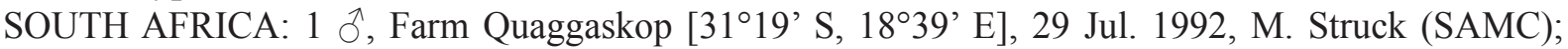

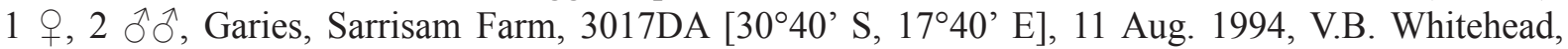
Phyllopodium pumilum (SAMC, RCMK); 1 क , Graafwater, 8 km West, 3218BA [32 ${ }^{\circ} 10^{\prime} \mathrm{S}, 18^{\circ} 40^{\prime}$ E], 24 Sep. 1998, V.B. Whitehead, (SAMC); 3 우, W. Cape, Rietvlei [3209' S, 1846’ E], 282 m, 22 Sep. 2011, L. Packer (LPCT); 3 우, 19.6 km S of Citrusdal [32 ${ }^{\circ} 43^{\prime}$ S, 1902' E], 6 Sep. 1991, K.

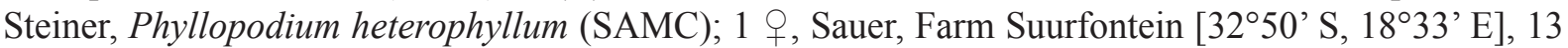
Sep. 2001, V.B. Whitehead, Phyllopodium (SAMC); 4 우오 , Sauer, Suurfontein, 3218DC [32 $50^{\circ}$ ' S, 1840’ E], 25 Aug. 1994, V.B. Whitehead, Phyllopodium heterophyllum (SAMC); 1 q, 1 o, Sauer, Suurfontein, 3218DC [3250' S, 1840’ E], 1 Sep. 1994, V.B. Whitehead, Phyllopodium heterophyllum

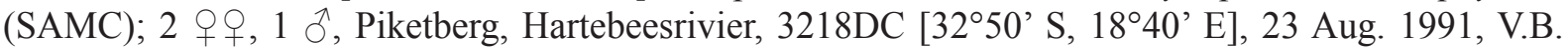
Whitehead, Polycarena (RCMK).
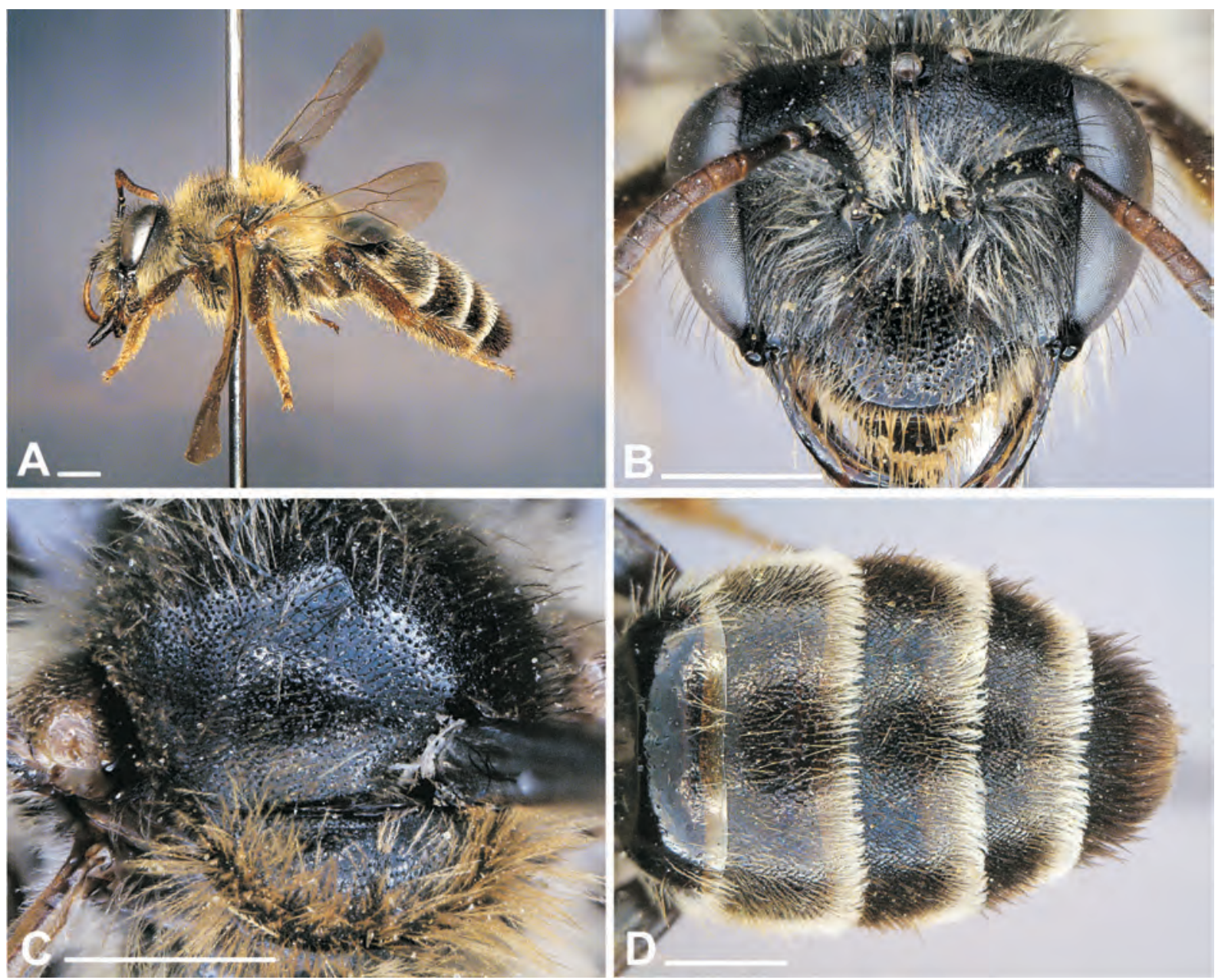

Fig. 7. Redivivoides karooensis sp. nov., + . A. Lateral view. B. Head. C. Scutum and scutellum. D. Metasoma (dorsal view). Scale bar: $1 \mathrm{~mm}$. 

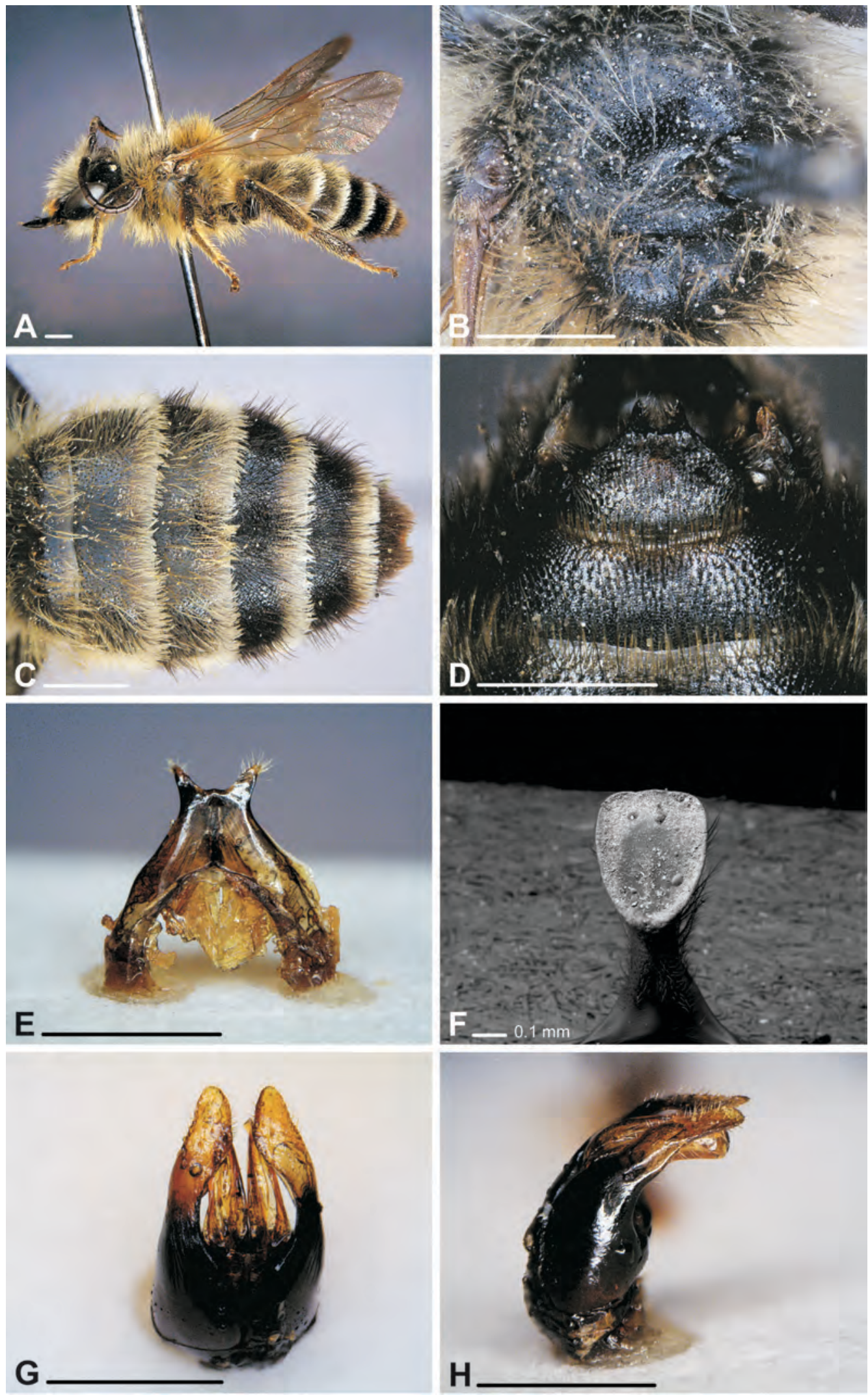

Fig. 8. Redivivoides karooensis sp. nov., ô. A. Lateral view. B. Scutum and scutellum. C. Metasoma (dorsal view). D. S6 (ventral view). E. S7 (dorsal view). F. S8, apical end (backscattered electron image). G. Genitalia (dorsal view). H. Genitalia (lateral view). Scale bar: $1 \mathrm{~mm}$. 


\section{Description}

Female

BODY LENGTH. 9.5-10.5 mm

HEAD. Head slightly wider than long. Integument black except mandibles and labrum largely dark reddish-brown. Face sparsely covered with long, yellowish-grey, erect hairs intermixed with black hairs especially along the inner eye margins and on vertex (Fig. 7B). Clypeus slightly convex, apically narrowly impunctate; medially densely covered with medium-sized punctures that become gradually smaller and denser towards the lateral and upper margins; surface between punctures shiny or superficially shagreened (Fig. 7B). Malar area medially narrow, almost linear. Antenna black, ventrally orange to reddish-brown.

Mesosoma. Integument black. Mesoscutal disc between punctures smooth and shiny; disc densely $(\mathrm{i}=0.5-1.0 \mathrm{~d})$ and finely punctate (Fig. 7C). Mesoscutum, scutellum, metanotum, mesepisternum and propodeum covered with long yellowish-brown erect hairs, black hairs intermixed on mesoscutum (Fig. 7C).

WINGS. Yellowish-brown; wing venation brown.

LEGS. Integument black to dark reddish-brown. Vestiture of femora whitish-yellow, on tibiae and tarsi dark brown to black, scopae very sparse, dark brown to whitish-grey.

METASOMA. Integument black, apical margins of terga narrowly translucent reddish-brown (Fig. 7D). T1 apically and T2 on disc sparsely covered with long erect yellowish-white hairs; T3 - T4 covered with short yellow to black hairs; apical tergal hair band missing on T1, on T2 - T4 broadly white (Fig. 7A, D). Prepygidial and pygidial fimbriae black. T1 almost impunctate, polished and shiny, T2 - T4 shiny, with very fine, superficial and sparse punctation that becomes progressively denser on apical terga (Fig. 7D).

\section{Male}

Body Length. 8.5-10.5 mm.

HEAD. Head slightly wider than long. Integument black except tip of mandible partly dark reddishbrown. Face densely covered with long, yellowish-brown, erect hairs intermixed with black hairs along the inner eye margins and on vertex. Malar area medially narrow, almost linear. Antenna black, ventrally yellowish to reddish-brown.

Mesosoma. Integument black. Mesoscutal disc between punctures smooth and shiny or superficially shagreened; disc densely ( $\mathrm{i}=0.5-1.0 \mathrm{~d}$ ) and finely punctate (Fig. 8B). Mesoscutum, scutellum, metanotum, mesepisternum and propodeum covered with long yellowish-brown erect hairs, on scutellum black hairs intermixed.

WiNGS. Yellowish-brown; wing venation brown.

LEGS. Integument black, tibiae and tarsi partly dark red-brown to yellowish-brown. Vestiture yellowishbrown.

Metasoma. Integument black, apical margins of terga narrowly translucent reddish-brown (Fig. 8C). T1 - T3 covered with long erect yellowish-white hairs; T4 - T6 covered with short black hairs; apical tergal hair band missing on T1, on T2 - T5 narrow and sparse, white (Fig. 8A, C). T1 almost impunctate, polished and shiny, T2 - T4 shiny, with very fine, superficial and sparse punctation that becomes progressively denser on apical terga (Fig. 8C). 
Terminalia. Genitalia (Fig. 8G-H), S6 (Fig. 8D), S7 (Fig. 8E) and terminal plate of S8 (Fig. 8F) as illustrated.

\section{Distribution}

The species is known from a few places in southern Namaqualand and low lying areas west of the Cedarberg Mountains (Fig. 4).

\section{Floral hosts}

Scrophulariaceae: Phyllopodium heterophyllum, Phyllopodium pumilum, Phyllopodium spec., Polycarena spec.

\section{Seasonal activity}

July - September.

Redivivoides namaquaensis sp. nov.

Figs 9, 10, 11

urn:1sid:zoobank.org:act:AEF68F53-B181-4D12-8D1C-980031A57F2E

\section{Diagnosis}

Males and females of $R$. namaquaensis sp. nov. can be separated from other Redivivoides species by their black to brown metasomal terga in combination with dark brown to black prepygidial fimbria and orange-brown pygidial fimbria (Figs 10D, 11C).

\section{Etymology}

Named after Namaqualand, the arid region in NW South Africa where this species occurs.

Type material (71 specimens)

\section{Holotype}

q, V.B. Whitehead, 16 Sep. 1999, Selago sp. / B009463" (SAMC). SOUTH AFRICA: N Cape, 3146' S, $20^{\circ} 03^{\prime}$ E, Middlepos, Elandsfontein.

\section{Paratypes}

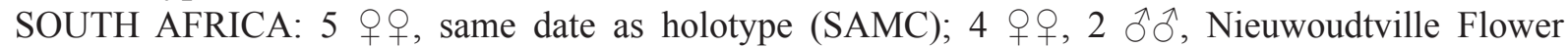

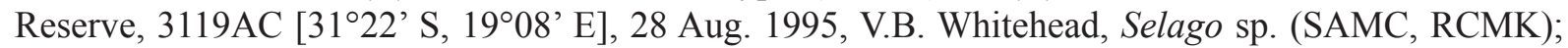

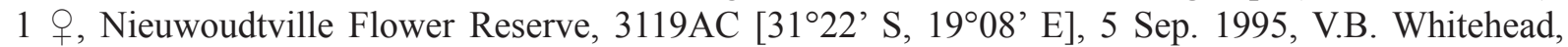

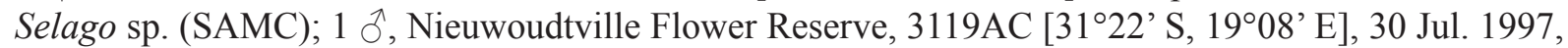
V.B. Whitehead, Selago sp. (SAMC); 1 ô, Nieuwoudtville Flower Reserve, Glen Lyon [3122' S,

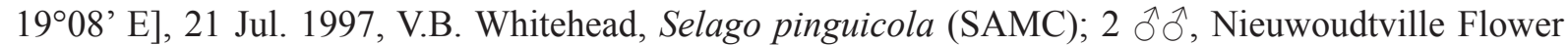
Reserve, Glen Lyon [31 ${ }^{\circ} 22^{\prime}$ S, $19^{\circ} 08^{\prime}$ E], 31 Jul. 1997, V.B. Whitehead, Selago pinguicola (SAMC);

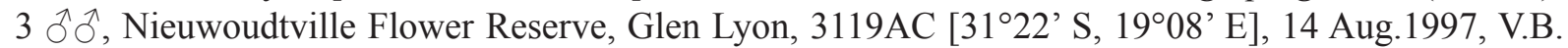

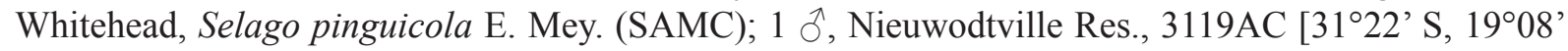
E], 19 Aug. 1986, V.B. Whitehead, Othonna (SAMC); 1 đ̃. N. Cape, Nieuwoudtville, Glen Lyon,

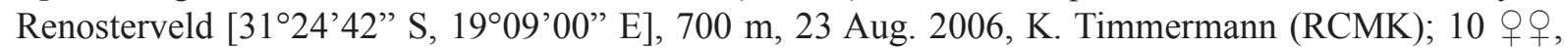

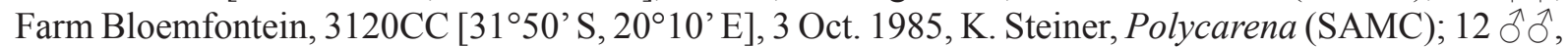
Farm Hartebeestfontein, 3120CC [31 ${ }^{\circ} 50^{\prime}$ S, 20¹0’ E], 27 Aug. 1990, K. Steiner, Arctotheca calendula

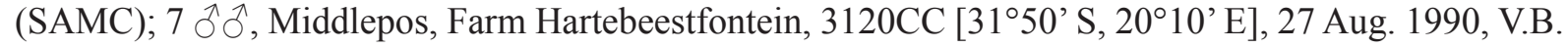
Whitehead, Arctotheca, Polycarena (SAMC, RCMK); 1 đo, $12 \mathrm{~km} \mathrm{~N}$ of Wuppertal, 3219AA [32 09' S, 19²' E], 30 Aug. 1990, V.B. Whitehead, Polycarena (SAMC); 3 ¡े $^{\dagger}, 5 \mathrm{~km} \mathrm{~S}$ of Bidouw, 3219AA [32¹0’ S, 19¹0’ E], 30 Aug. 1990, K. Steiner, Polycarena (SAMC); 9 우, Middelpos, Bloemfontein, 
3219BB [32¹0’ S, 1950’ E], 3 Oct. 1985, V.B. Whitehead, Polycarena (SAMC, RCMK); 2 우, 29,7

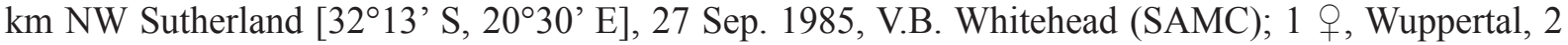
km N of, 3219AA [32 ${ }^{\circ} 15^{\prime}$ S, $19^{\circ} 12^{\prime}$ E], 29 Aug. 1990, V.B. Whitehead, Polycarena (SAMC); 1 ○, Holfontein, 20 km S Clanwilliam [32²0' S, 1855' E], 24 Aug. 1983, V.B. Whitehead, Hemimeris racemosa (SAMC); 1 을 Farm Kanolfontein, 3220AD [32²0’ S, 20²0’ E], 22 Sep. 1985, K. Steiner,

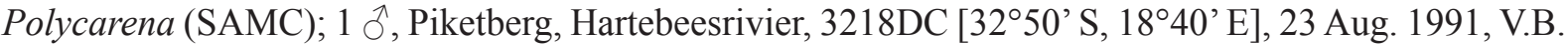

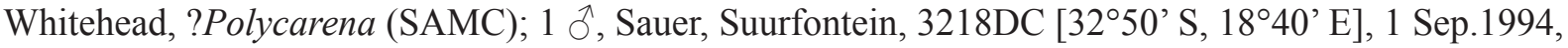
V.B. Whitehead, Phyllopodium heterophyllum (SAMC).

\section{Description}

\section{Female}

BODY LENGTH. 10.0-11.5 mm.

HEAD. Head slightly wider than long. Integument black except mandible and sometimes labrum partly dark reddish-brown. Face sparsely covered with long, whitish-grey, erect hairs intermixed with black hairs along the inner eye margins and on vertex (Fig. 10B). Clypeus mostly flat, apical margin almost

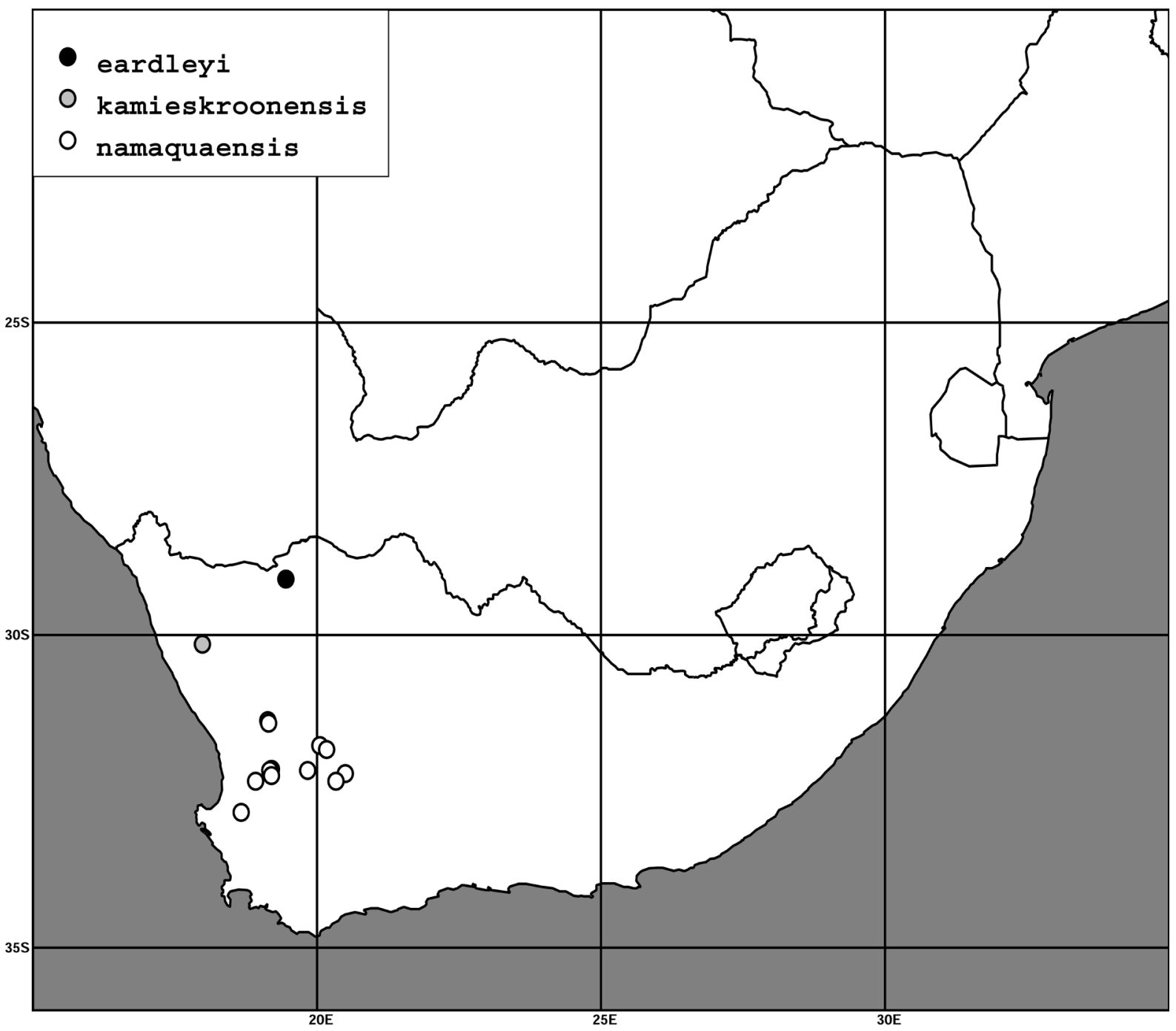

Fig. 9. Distribution of Redivivoides eardleyi sp. nov., R. kamieskroonensis sp. nov. and $R$. namaquaensis sp. nov. in South Africa. 
impunctate; medially densely covered with medium-sized punctures that become gradually smaller and denser towards lateral and upper margins; surface between punctures shiny (Fig. 10B). Malar area medially narrow, almost linear. Antenna black, ventrally dark orange to reddish-brown.

Mesosoma. Integument black. Mesoscutal disc between punctures smooth and shiny; disc densely $(\mathrm{i}=0.5-1.0 \mathrm{~d})$ and finely punctate (Fig. 10C). Mesoscutum, scutellum, metanotum, mesepisternum and propodeum covered with long yellowish-brown erect hairs, on the mesoscutum black hairs intermixed (Fig. 10C).

WINGS. Yellowish-brown; wing venation brown.

LEGS. Integument black to dark reddish-brown. Vestiture of femora whitish-yellow, on tibiae and tarsi dark brown to black, scopae yellowish-brown.

Meтаsомa. Integument dark brown to black, apical margins of terga narrowly translucent reddish to yellowish-brown (Fig. 10D). T1 - T4 covered with erect yellowish-white hairs, becoming progressively shorter from T1 to T4; apical tergal hair band sparse on T1, on T2 - T4 broadly white (Fig. 10A, D). Prepygidial fimbria dark brown to black, pygidial fimbria orange-brown. Terga impunctate, finely shagreened and matt (Fig. 10D).
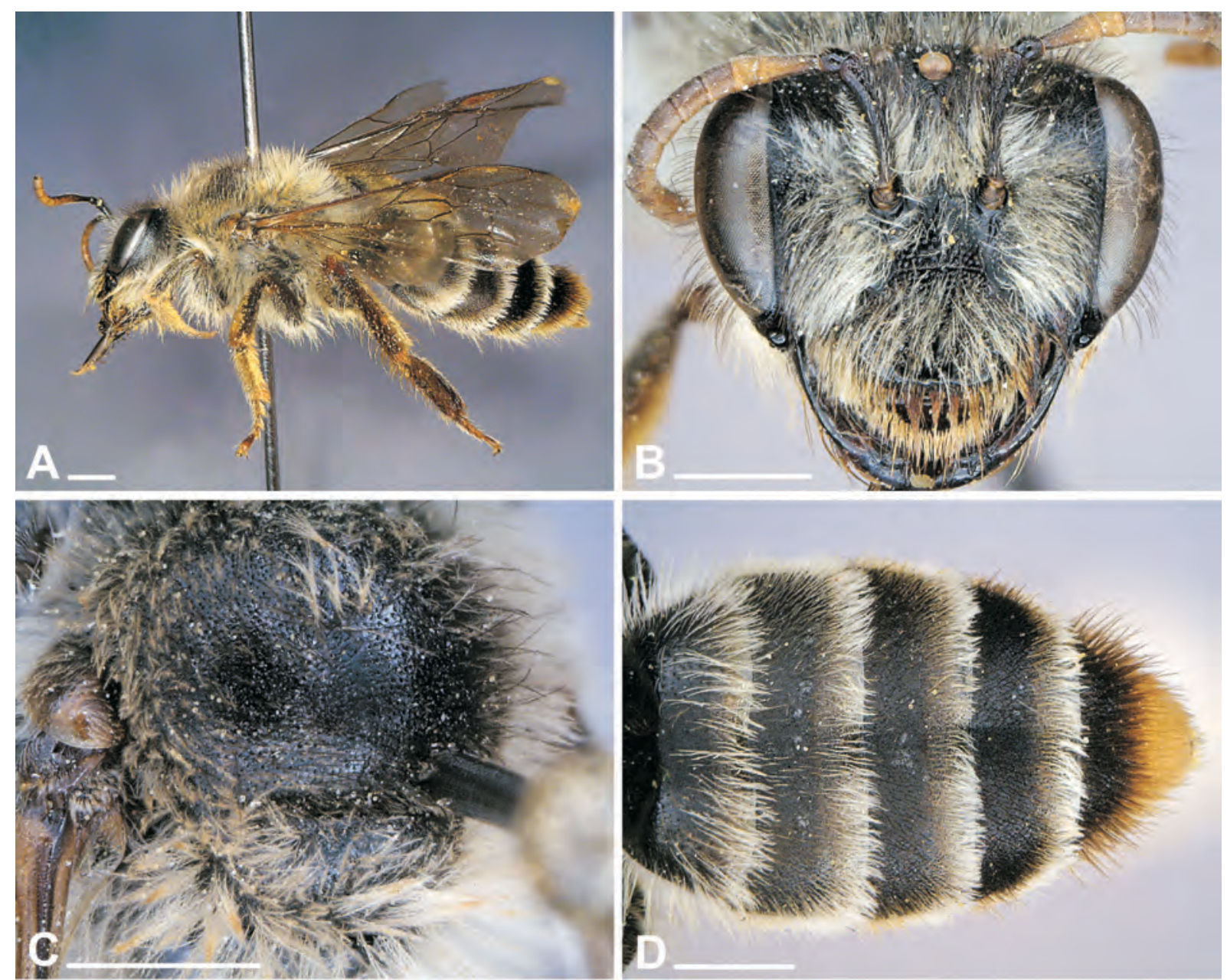

Fig. 10. Redivivoides namaquaensis sp. nov., +. A. Lateral view. B. Head. C. Scutum and scutellum. D. Metasoma (dorsal view). Scale bar: $1 \mathrm{~mm}$. 

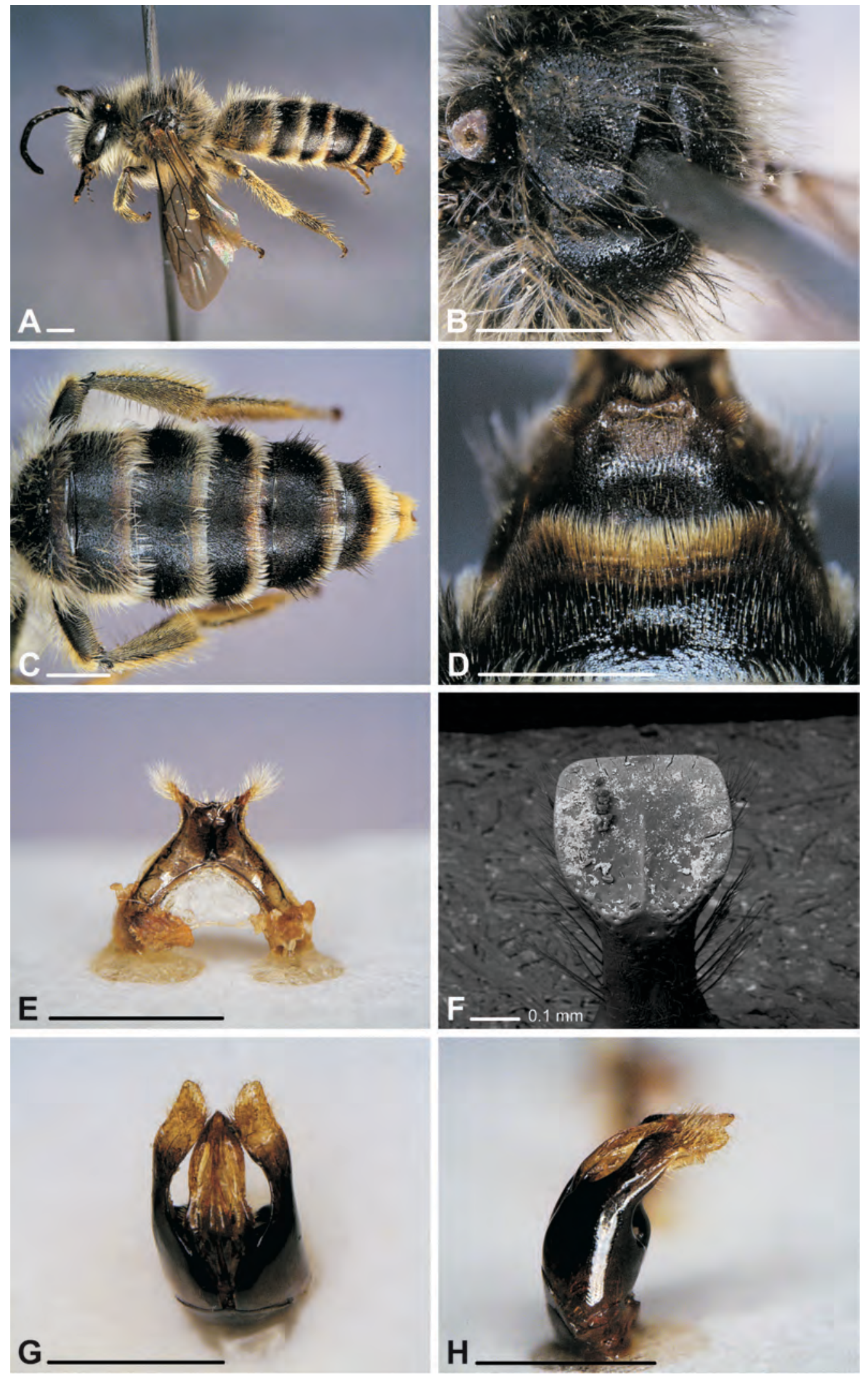

Fig. 11. Redivivoides namaquaensis sp. nov., $\widehat{\partial}$. A. Lateral view. B. Scutum and scutellum. C. Metasoma (dorsal view). D. S6 (ventral view). E. S7 (dorsal view). F. S8, apical end (backscattered electron image). G. Genitalia (dorsal view). H. Genitalia (lateral view). Scale bar: $1 \mathrm{~mm}$. 


\section{Male}

Body LENGTH. 9.0-10.0 mm.

HEAD. Head slightly wider than long. Integument black except tip of mandible partly dark reddishbrown. Face densely covered with long, whitish-grey, erect hairs intermixed with black hairs along the inner eye margins and on vertex. Malar area medially narrow, almost linear. Antenna black, ventrally dark brown.

MESOSOMA. Integument black. Mesoscutal disc between punctures smooth or superficially shagreened and shiny; disc densely ( $\mathrm{i}=0.5 \mathrm{~d}$ ) and very finely punctate (Fig. 11B). Mesoscutum, scutellum, metanotum, mesepisternum and propodeum covered with long white to yellowish-grey erect hairs, partly intermixed with a few black hairs.

WINGS. Yellowish-brown; wing venation brown.

LEGS. Integument black to reddish-brown. Vestiture whitish to yellowish-brown.

METASOMA. Integument dark brown to black, apical margins of terga narrowly translucent reddish to yellowish-brown (Fig. 11C). T1 - T3 densely covered with long, erect yellowish-brown hairs, on T3 intermixed with black hairs; T4 - T6 covered with short black hairs; apical tergal hair band missing on $\mathrm{T} 1$, on T2 - T5 narrow and sparse, white; apical fringe of T7 orange (Fig. 11A, C). Terga impunctate, finely and densely shagreened, matt (Fig. 11C).

Terminalia. Genitalia (Fig. 11G-H), S6 (Fig. 11D), S7 (Fig. 11E) and terminal plate of S8 (Fig. 11F) as illustrated.

\section{Distribution}

This species has the centre of its distribution on the Bokkeveld Plateau and in the Roggeveld Mountains with a few records southwest of that area (Fig. 9).

\section{Floral hosts}

Asteraceae: Arctotheca calendula, Arctotheca spec., Othonna spec.; Scrophulariaceae: Hemimeris racemosa, Phyllopodium heterophyllum, Polycarena spec., Selago pinguicola, Selago spec..

\section{Seasonal activity}

July - October.

\section{Redivivoides simulans Michener, 1981}

Figs 12, 13, 14

Redivivoides simulans Michener, 1981: 121-122, figs 80, $82-84$ (p. 43), 97 (p. 48), Holotype 9 (type locality: Clanwilliam, South Africa) (Snow Entomological Museum, University of Kansas, Lawrence).

\section{Diagnosis}

Females of $R$. simulans can be separated from other Redivivoides species by a combination of the following characters: metasomal terga at least partly red (at least on a narrow stripe on the apical part of the discs of T1 - T3), metasomal terga with surface between punctures smooth and shiny (Fig. 12D), scutum at least on the disc between punctures smooth and shiny (Fig. 12C), and head about as long as wide (Fig. 12B). These characters also apply to males (Fig. 13C) but genitalia and S6 - S8 (Fig. 13D-H) should be checked to avoid potential confusion with the unknown male of $R$. kamieskroonensis. 
Both sexes of $R$. simulans were described in detail by Michener (1981).

\section{Material examined}

Specimens examined (56 specimens): SOUTH AFRICA: 2 우, $40 \mathrm{~km}$ N Port Nolloth [28 $54^{\prime} 3^{\prime \prime} \mathrm{S}$,

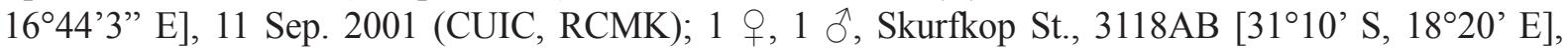
18 Aug. 1983, V.B. Whitehead, white Hermannia prostrate (SAMC); 1 , 1 đ̂, Farm Sarrisam, 3017DA [3040’ S, 1740’ E], 14 Aug. 1993, K. Steiner, Hermannia sp. (SAMC); 1 q, Ouberg Pass, 27 km SE Vanrhynsdorp, Fynbos [ $31^{\circ} 48^{\prime} 07^{\prime \prime}$ S, 18 $8^{\circ} 55^{\prime} 00^{\prime \prime}$ E], 380 m, 9 Aug. 2011, M. Kuhlmann

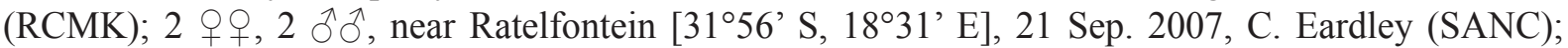

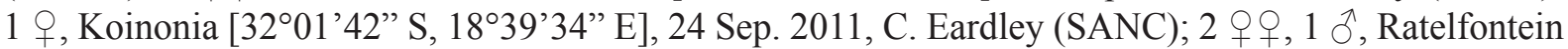
/ Olaf Bergfontein [3202' S, $18^{\circ} 35^{\prime}$ E], 7 Oct. 1995, F.W., S.K. \& R.W. Gess, visiting yellow fls. semiprostrate Hermannia sp., Sterculiaceae, 95/96/273 (AMGS); 2 우, Trawal, 15 km SSW [32 02 ' S,

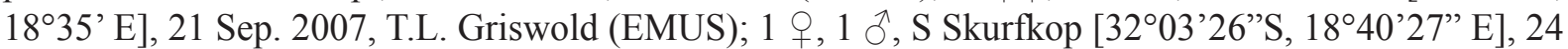

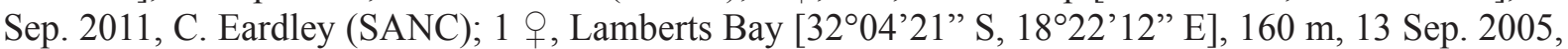

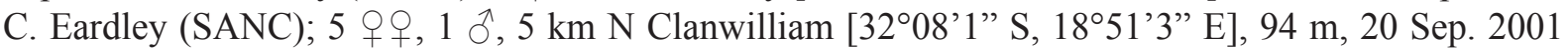

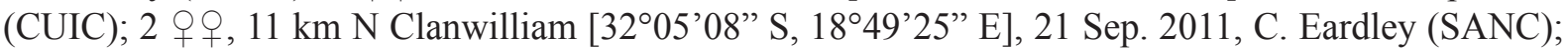

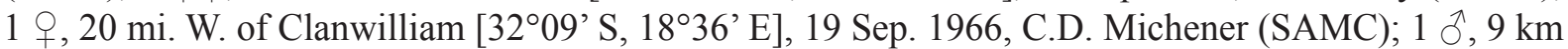

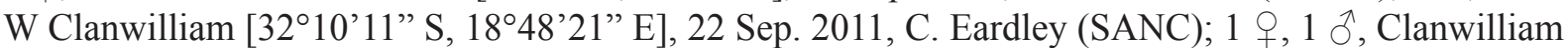
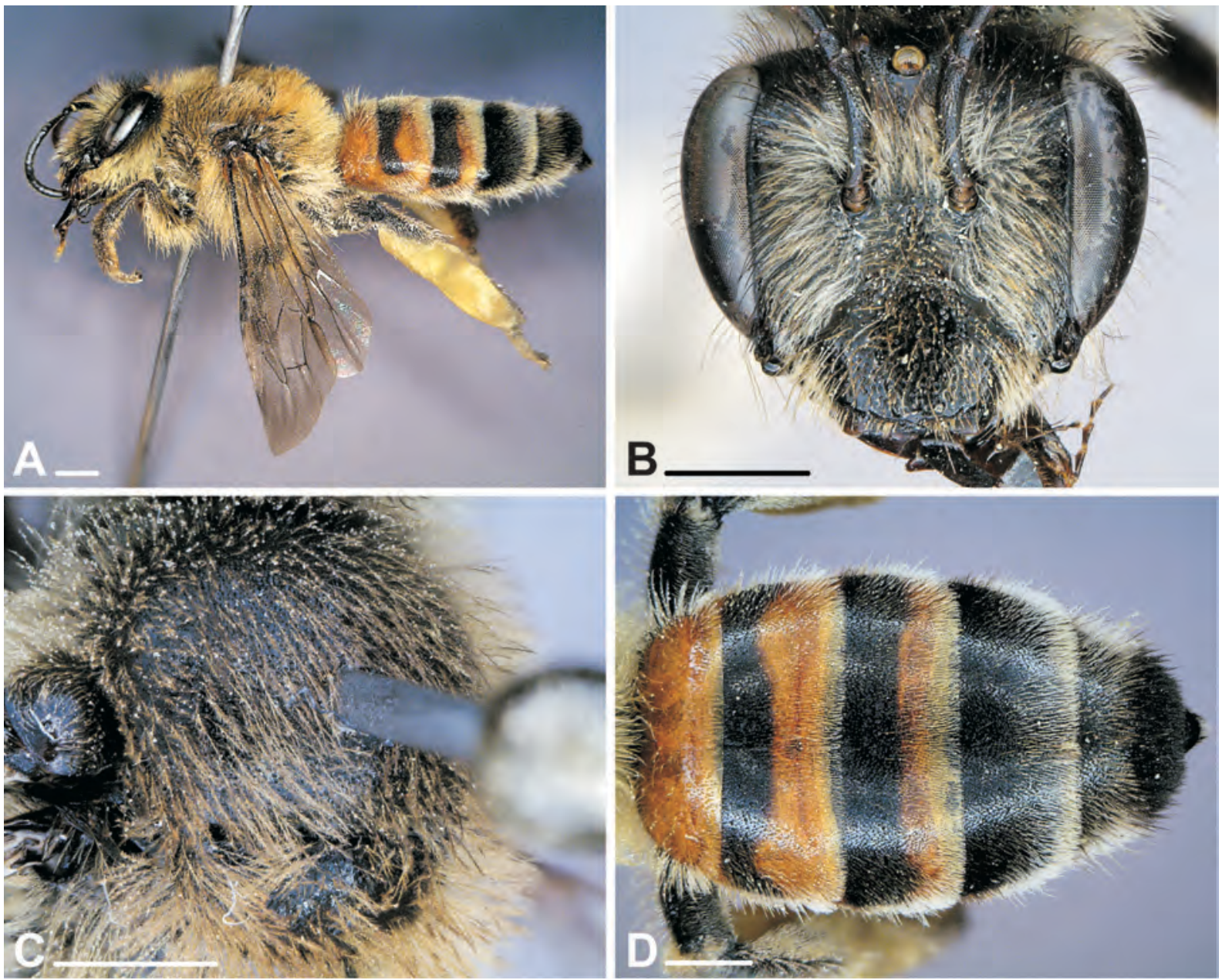

Fig. 12. Redivivoides simulans Michener, 1981, +. A. Lateral view. B. Head. C. Scutum and scutellum. D. Metasoma (dorsal view). Scale bar: $1 \mathrm{~mm}$. 

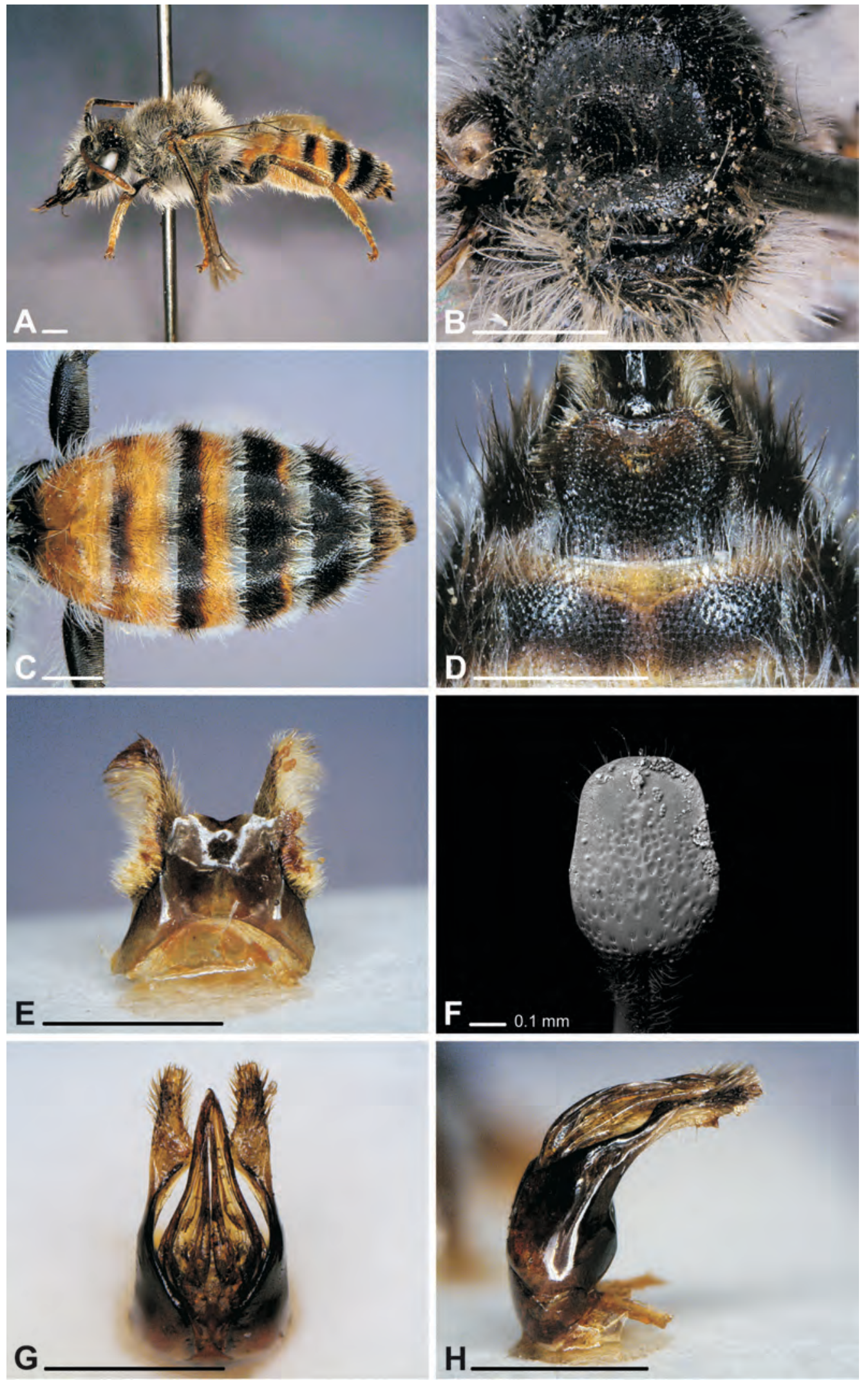

Fig. 13. Redivivoides simulans Michener, 1981, O. A. Lateral view. B. Scutum and scutellum. C. Metasoma (dorsal view). D. S6 (ventral view). E. S7 (dorsal view). F. S8, apical end (backscattered electron image). G. Genitalia (dorsal view). H. Genitalia (lateral view). Scale bar: $1 \mathrm{~mm}$. 
[3210' S, 1853' E], 8 Sep. 1966, M. \& C.D. Michener (EMUS); 1 q, Droogerivier, Sandberg Sta.,

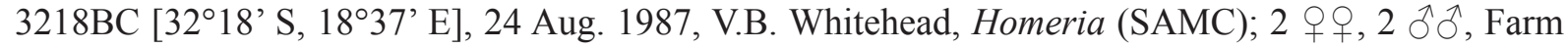

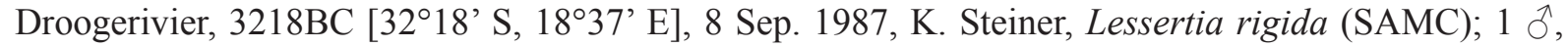
Droogerivier, Sandberg Sta., 3218BC [32¹8’ S, 18³7’ E], 27 Aug. 1987, V.B. Whitehead, Homeria

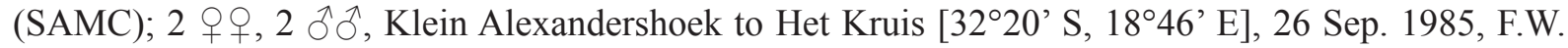

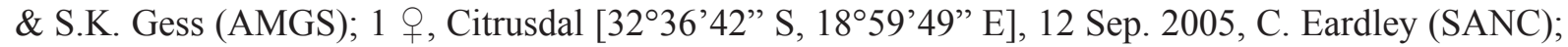

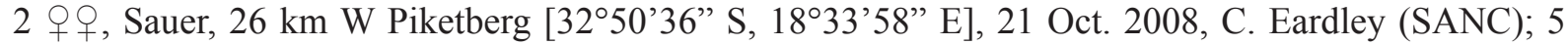
우오, Sauer, 26 km W Piketberg [32॰50'37’ S, 1833'58” E], 21 Oct. 2008, BN Danforth, on Hermannia (CUIC); 4 우, Sauer [3250' S, 18³4' E], 21 Oct. 2008, T.L. Griswold (EMUS); 1 ㅇ, Atlantis, 3 km W, [333' S, 18²7' E], 150 m, 8-12 Oct. 2002, M.E. Irwin, F.D. Parker (EMUS); 1 o, Ganzekraal, 3318CB [3340’ S, 18²0’ E], 22 Sep. 1999, K. Steiner, Nemesia affinis (SAMC).

\section{Additional material}

Additional records from the database of the South African Museum, Cape Town (material in SAMC, no data on number or sex of specimens available): SOUTH AFRICA: Goegap Reserve, $4 \mathrm{~km}$ from tarred road on circular drive, Springbok [29 $40^{\prime}$ S, $18^{\circ} 00^{\prime}$ E], 13 Aug. 1993, Whitehead, Zygophyllum;

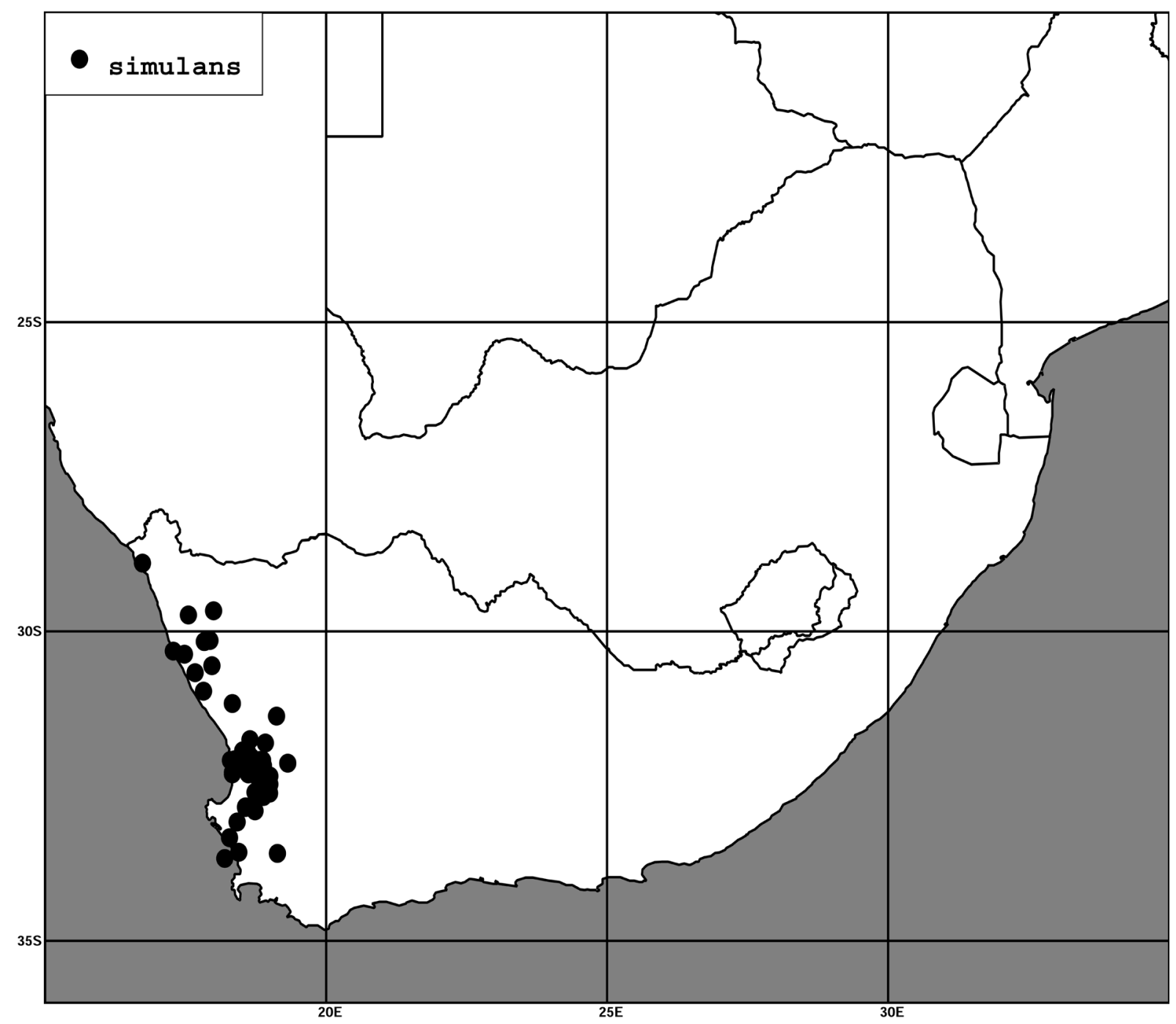

Fig. 14. Distribution of Redivivoides simulans Michener, 1981 in South Africa. 
Klipfontein [2944' S, 17³3'], 3 Aug. 1988, Whitehead, Zygophyllum, Bowesdorp, L. Namaqualand

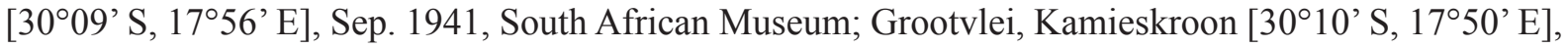

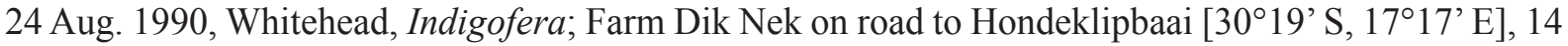

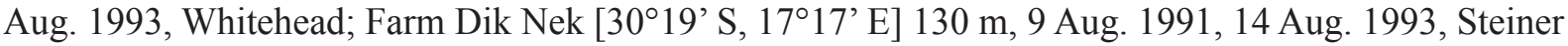
(SAMC); Diknek, Garies [30 $19^{\prime}$ S, $17^{\circ} 17^{\prime}$ E], 18 Aug. 1995, Whitehead / Macpherson, Nemesia;

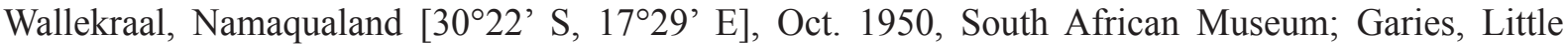

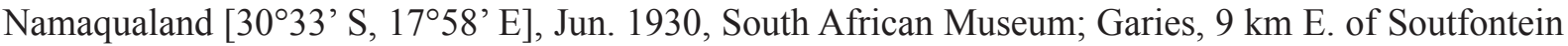
[30³3' S, 1758' E], 22 Aug. 1990, Whitehead, Lebeckia; Kotzesrus, 12.6 km N. on rd to Groenrivier

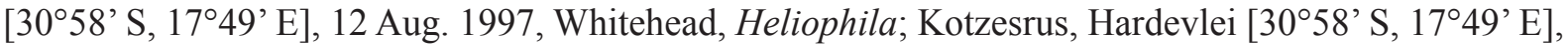
28 Aug. 1997, Whitehead, Hermannia; Nieuwoudtville [3122' S, 1907’ E], 31 Aug. 1985, Whitehead / Macpherson, Lotonotis serpens; Garies, Farm Sariesaam [3040' S, 1740' E], 14 Aug. 1993, Steiner; $6.5 \mathrm{~km} \mathrm{~N}$ of Klawer t/o on N7 [31 ${ }^{\circ} 45^{\prime}$ S, 18 ${ }^{\circ} 39^{\prime}$ E], 6 Aug. 1989, Steiner, Homeria minuata; Skurfkop station [31 ${ }^{\circ} 56^{\prime}$ S, $18^{\circ} 36^{\prime}$ E], 18 Aug. 1983, Whitehead, Hermannia; Lamberts Bay [3205' S, $18^{\circ} 18^{\prime}$ E], 28 Sep. 1977, Whitehead; Farm Skarpdam [3205'S, 18.22'E], 9 Sep. 1987, Steiner/Whitehead, Nemesia; $12 \mathrm{~km} \mathrm{~N}$ of Clanwilliam [3205' S, 1852' E], 11 Aug. 1985, Whitehead, Hermannia; $11 \mathrm{~km} \mathrm{~N}$ of Clanwilliam [3206' S, 18 ${ }^{\circ} 52^{\prime}$ E], 21 Aug. 1985, Whitehead / Macpherson; Kompagniesdrif, 19 km

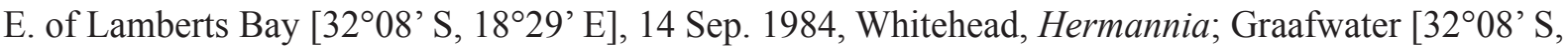
$18^{\circ} 35^{\prime}$ E], Oct. 1947, South African Museum Expedition; $10 \mathrm{~km}$ E of Bidouw Valley [3208' S, 19¹9' E], 8 Sep. 1985, Picker; Clanwilliam [32¹0' S, 1853' E], 11 Aug. 1984, Picker; Ramskop campsite, Clanwilliam [32 ${ }^{\circ} 10^{\prime}$ S, 18 ${ }^{\circ} 53^{\prime}$ E], 22 Aug. 1984, Whitehead / Macpherson, Trachyandra muricata; Leipoldtville, Elands Bay [32 ${ }^{\circ} 2^{\prime}$ S, $18^{\circ} 28^{\prime}$ E], Oct. 1947, South African Museum Expedition; Elands

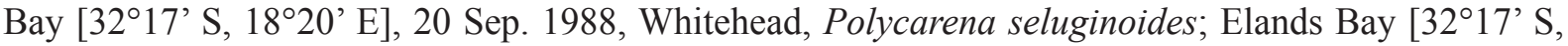
$18^{\circ} 20^{\prime}$ E], 26 Sep. 1985, Whitehead, Hermannia; Farm Skerpheuwel [32¹8’ S, 18²0’ E], 28 Aug. 1987, Steiner, Nemesia; Farm Droogerivier [32 $18^{\prime}$ S, $18^{\circ} 37^{\prime}$ E], 8 Sep. 1987, Steiner; Droogerivier (Droërivier), Sandberg sta. [32¹8' S, 18³7' E], 27 Aug. 1987, Whitehead, Homeria; 11 Aug. 1988, Whitehead, Cysticapnos; 8 Sep. 1987, Steiner, Lessertia rigida; Farm Droogerivier (Droërivier) [32¹8’ S, $18^{\circ} 37^{\prime}$ E], 27 Aug. 1987, 8 Sep. 1987, Steiner, Lessertia rigida / Cysticapnos vesicarius; Paleisheuwel, Alexanderhoek [ $32^{\circ} 18^{\prime}$ S, $18^{\circ} 43^{\prime}$ E] 12 Sep. 1991, Whitehead, Cysticapnos; Holfontein, $20 \mathrm{~km} \mathrm{~S}$ of Clanwilliam [32 $20^{\prime}$ S, $18^{\circ} 55^{\prime}$ 'E], 29 Aug. 1984, Whitehead / Steiner, Hermannia; 28.8 $\mathrm{km}$ N of Citrusdal t/o [32 $20^{\prime}$ S, $19^{\circ} 00^{\prime}$ E], 8 Aug. 1984, Whitehead, Hermannia; Farm Klawervlei, $23 \mathrm{~km}$ south of Clanwilliam [32 $23^{\prime}$ S, $18^{\circ} 56^{\prime}$ E], 20 Aug. 1984, Whitehead, Hermannia, Lachenalia mutabilis; Koraanshoogte, 13.5 km north of Citrusdal t/o [32 $28^{\prime}$ S, $\left.19^{\circ} 00^{\prime} \mathrm{E}\right], 20$ Aug. 1984, Whitehead / Macpherson, Hermannia; Oorwinningsfontein, $33 \mathrm{~km} \mathrm{~N}$ of Piketberg [32 $36^{\prime} \mathrm{S}, 1^{\circ} 44^{\prime} \mathrm{E}$ ], 30 Aug. 1987, Whitehead, Hermannia; 30 Jul. 1987, Whitehead, Hermannia; Eendekuil, Aroenfontein [3240' S, $18^{\circ} 53^{\prime} \mathrm{E}$ ], 19 Aug.1992, Whitehead; $1 \mathrm{~km} \mathrm{~S}$ of Droëryskloof Sta., Eendekuil [3240' S, 1853’ E], 30 Aug. 1986, Whitehead, Hermannia; Sauer, Suurfontein [3250’ S, 1840’ E], 1 Sep. 1994, Whitehead / Macpherson, Nemesia; Piketberg [3254' S, 1844' E], 21 Sep. 1985, Whitehead; Berg River, Jantjiesfontein $\left[33^{\circ} 05^{\prime} \mathrm{S}, 18^{\circ} 25^{\prime} \mathrm{E}\right], 25$ Sep. 1991, Whitehead; Hopefield, Jantjiesfontein $\left[33^{\circ} 05^{\prime} \mathrm{S}\right.$,

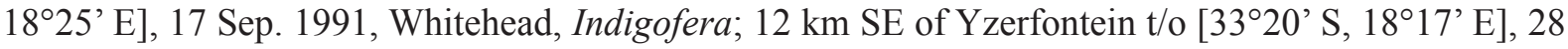

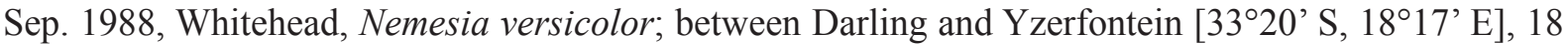

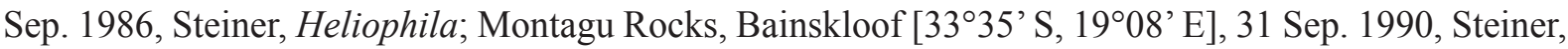
Moraea ramosissima; Ganzekraal [3340’ S, 18²0’ E], 22 Sep. 1999, Steiner, Nemesia affinis; Darling road, 18 Sep. 1986, Whitehead, Heliophila.

\section{Distribution}

This is the most common and widespread of all Redivivoides species and has been found in most parts of the winter rainfall area (Fig. 14). 


\section{Floral hosts}

Asphodelaceae: Trachyandra muricata; Brassicaceae: Heliophila spec.; Fabaceae: Indigofera spec., Lebeckia spec., Lessertia rigida, Lotonotis hirsuta (= serpens); Fumariaceae: Cysticapnos vesicaria; Hyacinthaceae: Lachenalia mutabilis; Iridaceae: Moraea miniata, M. ramosissima, Moraea spec.; Scrophulariaceae: Nemesia affinis, N. versicolor, Nemesia spec., Polycarena phyllopodioides (= seluginoides); Sterculiaceae: Hermannia spec.; Zygophyllaceae: Zygophyllum spec.

\section{Seasonal activity}

(June) July - October.

\section{Redivivoides variabilis $\mathrm{sp}$. nov.}

Figs $15,16,17$

urn:1sid:zoobank.org:act:8353A5DA-3526-4FDC-A7EF-E31070DB45EF

\section{Diagnosis}

Females and males of $R$. variabilis can be separated from other Redivivoides species by their black to brown metasomal terga which are smooth and shiny between punctures and that lack white apical hair bands (Figs 15E-F, 16E). This is the only Redivivoides species where terga have an intense oily bluish shine.

\section{Etymology}

The species is named after the colour variation of the females.

\section{Type material (31 specimens)}

\section{Holotype}

ㅇ, 17 Aug. 1999, K. Steiner / Host Plant: Melolobium obcordatum / SAM-HYM-B009467 (SAMC). SOUTH AFRICA: N.C. Prov., Grootvlei, 3017BB, 1750’E, 30¹0’S.

\section{Paratypes}

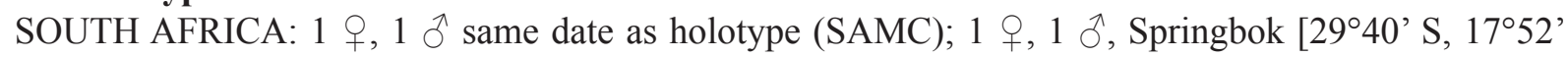
E], 7 Sep. 1966, C.D. Michener (SAMC); 3 q , Namaqualand, Springbok, Goegap Nature Res. (hills) [2941' S, 1759' E], 8-10 Sep. 1992, F.W. \& S.K. Gess, on yellow fls. of Lebeckia spinescens Harv. (Papilionaceae), 92/93/41, (AMGS); 2 우, Dassiefontein Farm, 14 km E Kammieskroon (sic) [3009’

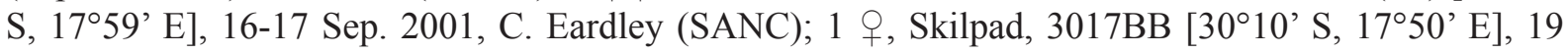
Aug. 1999, K. Steiner, Nemesia anisocarpa (SAMC); 1 q, Kamieskroon, Dassiefontein, 3017BB [30¹0' S, 1750' E], 7 Sep. 1986, K. Steiner, Lotononis (SAMC); 1 ㅇ, Farm Grootvlei, 3017BB

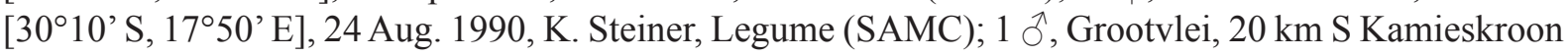

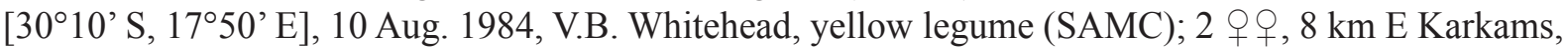
3017BD [30²0' S, 1750' E], 10 Aug. 1985, V.B. Whitehead, Nemesia \& Lachenalia (SAMC); 1 ㅇ,

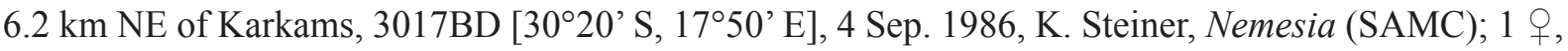
Garies, Welkom Farm, 3018CA [3040’ S, 18¹0' E], 30 Sep. 1988, V.B. Whitehead, Lotononis serpens (SAMC); 1 , N. Cape, Nieuwoudtville, Flower Reserve East [31²1'56” S, 1908'52” E], 735 m, 10 Aug. 2004, M. Kuhlmann (RCMK); 1 o (black form), N. Cape, Nieuwoudtville, Flower Reserve East

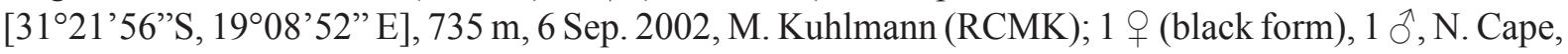
Nieuwoudtville, Flower Reserve East [31 ${ }^{\circ} 21^{\prime} 56^{\prime \prime}$ S, 1908'52”E], 735 m, 3 Sep. 2003, M. Kuhlmann, on Oxalis spec. (RCMK); 1 + , Nieuwoudtville, Farm Glenlyon, 3117AC [3121' S, 1908' E], 14 Aug. 1997, V.B. Whitehead, Lotononis serpens (SAMC); $10^{\wedge}$, Nieuwoudtville Flower Reserve [31 $22^{\circ} \mathrm{S}, 19^{\circ} 08^{\prime} \mathrm{E}$ ], 2 Aug. 1984, V.B. Whitehead, Lotononis serpens (SAMC); 2 우, W. Cape, $24 \mathrm{~km} \mathrm{~N}$ of Garies [30 23' S, 1754’ E], 777 m, 25 Sep. 2011, L. Packer (LPCT, RCMK); 1 đે, N. Cape, Nieuwoudtville, Glen 

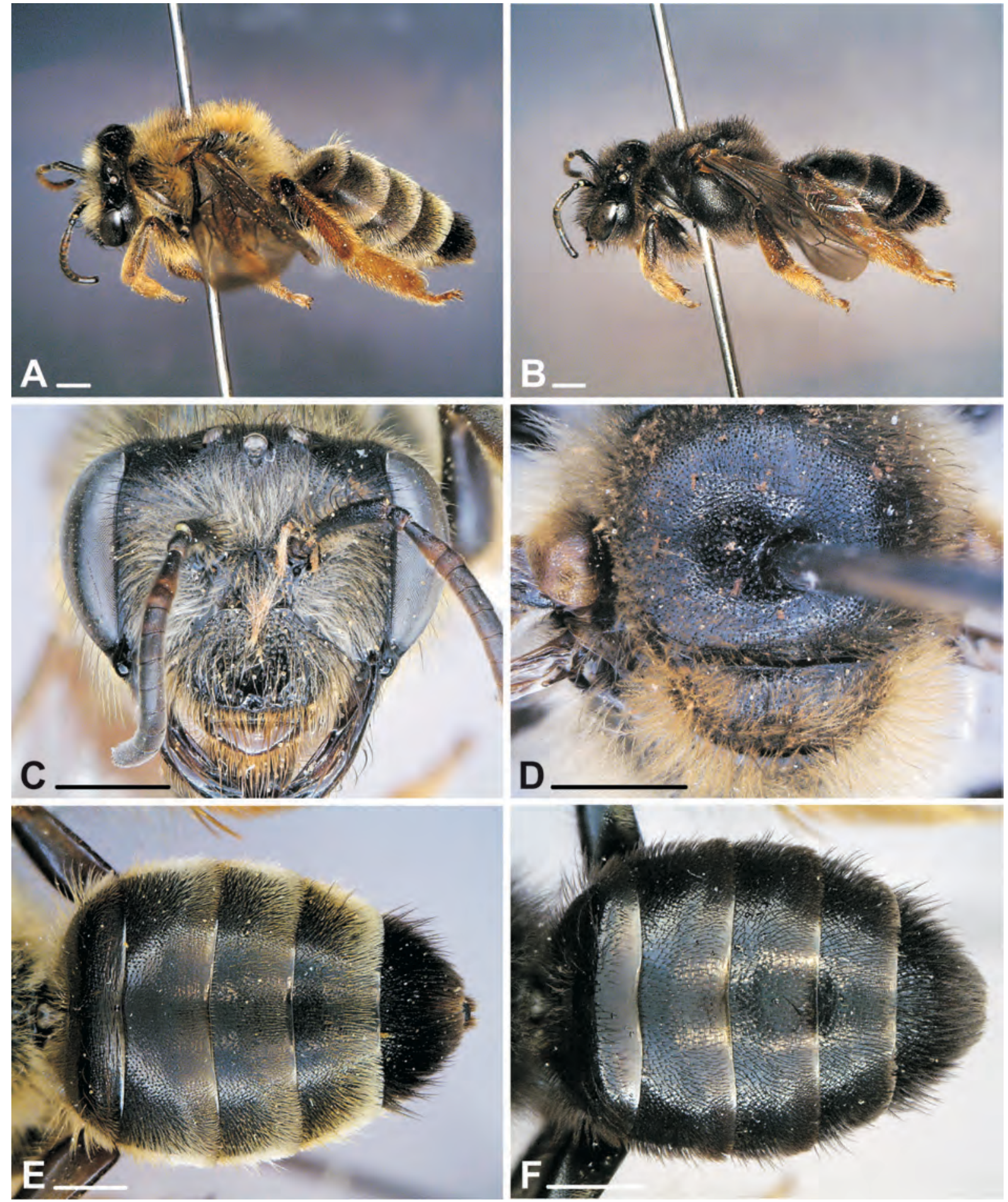

Fig. 15. Redivivoides variabilis sp. nov., ${ }^{+}$. A. Lateral view (light form). B. Lateral view (black form). C. Head. D. Scutum and scutellum. E. Metasoma (dorsal view) (light form). F. Metasoma (dorsal view) (black form). Scale bar: $1 \mathrm{~mm}$. 

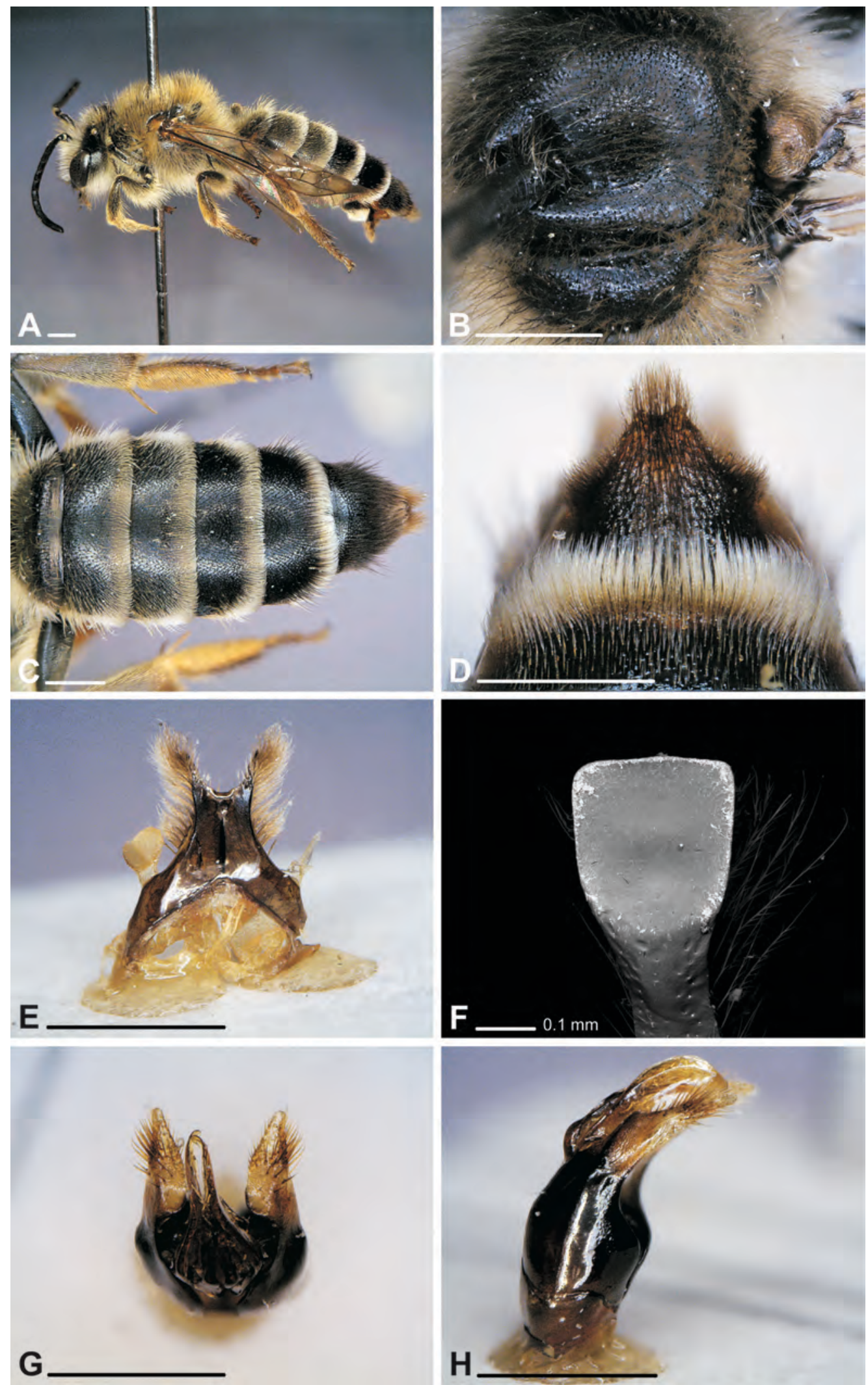

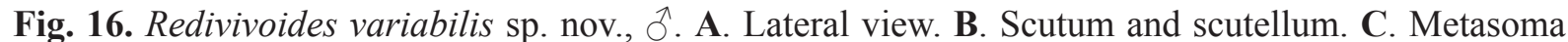
(dorsal view). D. S6 (ventral view). E. S7 (dorsal view). F. S8, apical end (backscattered electron image). G. Genitalia (dorsal view). H. Genitalia (lateral view). Scale bar: $1 \mathrm{~mm}$. 
Lyon, Renosterveld [3124'03” S, 1908'34” E], 700 m, 18 Aug. 2004, M. Kuhlmann (RCMK); 1 ㅇ (black form), Keiski Mts., 5 km S Farm Nooiensrivier, dolerite hill [3145'54”S, 1950’17” E], 1270 m, 29 Aug. 2010, M. Kuhlmann (RCMK); 1 q (black form), Keiski Mts., 5 km S Farm Nooiensrivier,

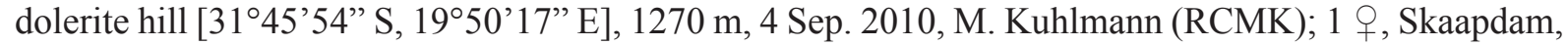
11 km E Lamberts Bay [3205’ S, 18²2’E], 9 Sep. 1987, V.B. Whitehead, Nemesia (SAMC); 1 ㅇ (black form), Clanwilliam, Ramskop [32¹0’ S, 1853' E], 21 Aug. 1984, V.B. Whitehead \& M. Macpherson, Homeria minuta (SAMC).

\section{Description}

\section{Female}

Body LENGTH. 12.0-13.0 mm.

HEAD. Head slightly wider than long. Integument black except median part of mandible and sometimes labrum partly dark reddish-brown. Face sparsely covered with long, whitish-grey (in the dark form all black, Fig. 15B), erect hairs intermixed with black hairs along the inner eye margins and on vertex

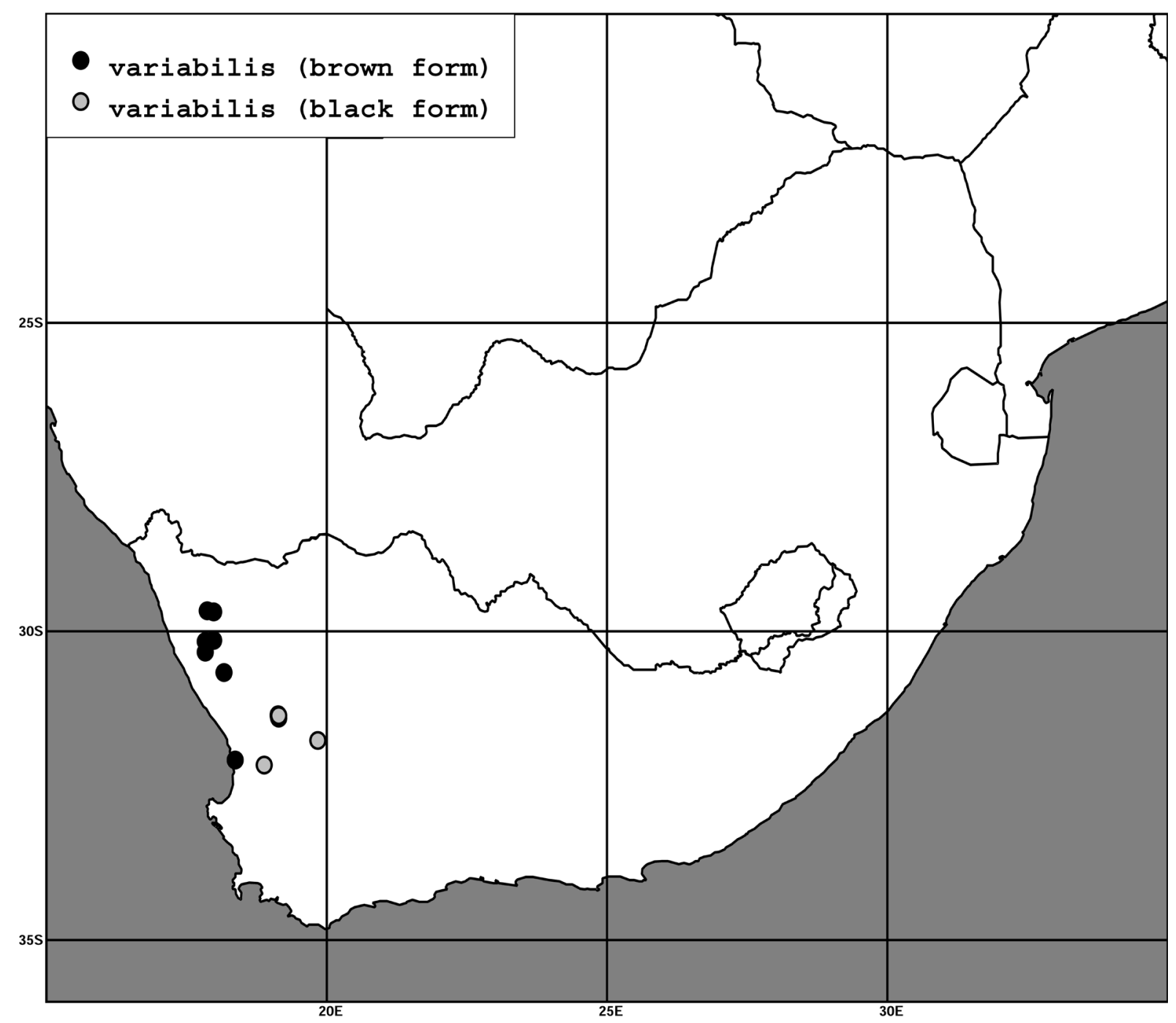

Fig. 17. Distribution of Redivivoides variabilis sp. nov. in South Africa. 
(Fig. 15C). Clypeus mostly flat, apically almost impunctate, punctures here large and scattered becoming rapidly smaller and denser towards the upper edge; surface between punctures shiny (Fig. 15C). Malar area medially narrow, almost linear. Antenna black, ventrally sometimes partly dark reddish-brown.

Mesosoma. Integument black, tegulae partly yellowish-brown. Mesoscutal disc between punctures smooth and shiny; disc densely $(\mathrm{i}=0.5-1.0 \mathrm{~d})$ and finely punctate (Fig. 15D). Mesoscutum, scutellum, metanotum, mesepisternum and propodeum covered with long yellowish-brown erect hairs, on the disc of mesoscutum and scutellum some black hairs intermixed (in the dark form all black, Fig. 15B).

WINGS. Yellowish-brown; wing venation brown.

LEGS. Integument black to yellowish-brown. Vestiture yellowish-brown, scopae yellowish-brown. In the dark form hairs of femora and most of tibiae black or dark brown, on tarsi yellowish-brown, scopae darker yellowish-brown (Fig. 15B).

Mеталома. Integument black, except apical tergal margins partly narrowly brownish translucent; terga with intense oily bluish shine (Fig. 15E-F). T1 apically sparsely covered with a few long erect yellowish hairs; T2 - T4 covered with short yellowish-white hairs; apical tergal hair band missing on T1, on T2 - T4 very sparse and only laterally developed (Fig. 15A-E). In the dark form all hairs black, no apical tergal hair bands (Fig. 15B-F). Prepygidial fimbria dorsally black, laterally partly yellowish white (in dark form all black), pygidial fimbria black. Terga densely but finely punctate, smooth and shiny between punctures (Fig. 15E-F).

\section{Male}

BODY LENGTH. 12.0-13.0 mm.

HEAD. Head slightly wider than long. Integument black except tip of mandible partly dark reddish-brown. Face densely covered with long, whitish-grey to yellowish-brown, erect hairs intermixed with black hairs along the inner eye margins and on vertex. Malar area medially narrow, almost linear. Antenna black, ventrally dark reddish-brown.

Mesosoma. Integument black, tegulae partly yellowish-brown. Mesoscutal disc between punctures smooth and shiny; disc densely $(\mathrm{i}=0.5-1.0 \mathrm{~d}$ ) and finely punctate (Fig. 16B). Mesoscutum, scutellum, metanotum, mesepisternum and propodeum covered with long yellowish-brown erect hairs, on the disc of mesoscutum and scutellum some black hairs intermixed (Fig. 16B).

WiNGs. Yellowish-brown; wing venation brown.

LEGS. Integument black, tibiae and tarsi partly yellowish-brown. Vestiture yellowish-white.

METASOMA. Integument black, except apical tergal margins partly narrowly brownish translucent; T1 T3 with intense oily bluish shine, T4 - T5 less so (Fig. 16A, C). T1 completely and T2 on disc covered with long erect yellowish-white hairs; T2 - T3 densely covered with short erect yellowish-white either yellowish-white or black on T4 and black on T5 - T6; apical tergal hair band missing on T1, on T2 - T5 sparse and narrow, yellowish-white to white (Fig. 16A, C). Terga densely but finely punctate, smooth and shiny between punctures (Fig. 16C). T7 with pygidial plate that is reduced to a narrow longitudinal, slightly elevated and shiny ridge.

Terminalia. Genitalia (Fig. 16G-H), S6 (Fig. 16D), S7 (Fig. 16E) and terminal plate of S8 (Fig. 16F) as illustrated. 


\section{Distribution}

The species has been found in most parts of Namaqualand to the northern parts of the Roggeveld Mountains in the southeast (Fig. 17). The colour form with females all black is only known from the higher grounds of the south-eastern part of the species' range while the females with light brown pilosity mostly occur in lower areas and the north (Fig. 17). Colour variation is also known from Rediviva gigas Whitehead \& Steiner, 1993 and . parva Whitehead \& Steiner, 2001. In R. gigas there is no obvious geographical pattern of colour variation but the black form of $R$. parva seems to be concentrated in the north and in lower lying areas in the west of its range (Whitehead \& Steiner 2001).

\section{Floral hosts}

Fabaceae: Lebeckia spinescens, Lotonotis hirsuta (= serpens), Lotononis spec., Melolobium obcordatum; Hyacinthaceae: Lachenalia spec.; Iridaceae: Moraea miniata; Oxalidaceae: Oxalis spec.; Scrophulariaceae: Nemesia anisocarpa, Nemesia spec.

\section{Seasonal activity}

August - September.

\section{Key to Redivivoides species}

\section{Females}

1. Metasomal terga extensively and brightly red (Figs 2D, 6D, 12D), rarely only on a narrow stripe

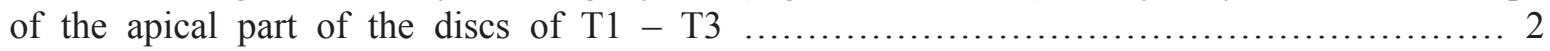

- Metasomal terga black or brown (Figs 5D, 7D, 10D, 15E-F), sometimes apical tergal margins narrowly translucent dark reddish brown

2. Scutum impunctate, shagreened and matt (Fig. 2C)

R. capensis sp. nov.

- Scutum finely punctate and at least on disc between punctures smooth and shiny (Figs 6C, 12C) ... 3

3. Metasomal terga finely shagreened and with a dull shine (Fig. 6D); head distinctly wider than long (Fig. 6B) ...................................................... R. kamieskroonensis sp. nov.

- Metasomal terga between punctures smooth and shiny (Fig. 12D); head only slightly wider than long (Fig. 12B) .................................................. R. simulans Michener, 1981

4. Metasomal terga finely shagreened and dull (Fig. 10D); prepygidial and pygidial fimbria yellowish brown (Fig. 10D) ............................................. namaquaensis sp. nov.

- Metasomal terga between punctures smooth and shiny (Figs 5D, 7D, 15E-F); prepygidial and

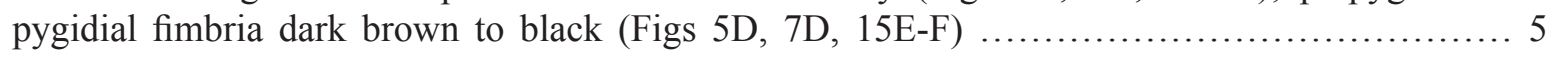

5. Metasomal terga without white apical tergal hair bands (Fig. 15E-F); terga with intense oily

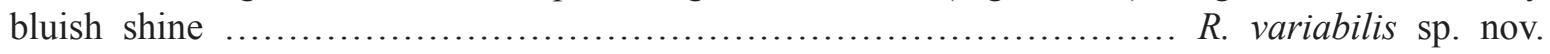

- Metasomal terga with white apical tergal hair bands (Figs 5D, 7D); terga without oily bluish shine ... 6

6. Disc of T2 sparsely punctate ( $i=2-3$ d); punctures minute (Fig. 5D); head and clypeus as in Fig. $5 \mathrm{~B}$ $R$. eardleyi sp. nov.

- Disc of T1 densely punctate $(\mathrm{i}=\mathrm{d}$ ); punctures larger (Fig. 7D); head and clypeus as in Fig. 7B R. karooensis sp. nov. 
Males

The males of $R$. eardleyi sp. nov. and $R$. kamieskroonensis sp. nov. are unknown.

1. Metasomal terga extensively and brightly red, rarely only on a narrow stripe of the apical part of the

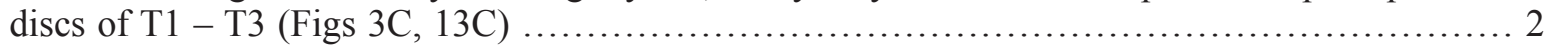

- Metasomal terga black or brown, sometimes apical tergal margins narrowly translucent dark reddish

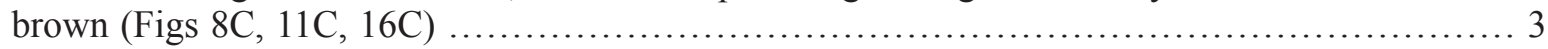

2. Scutum impunctate, shagreened and matt (Fig. 3B); S6 - S8 and genitalia as in Fig. 3D-H R. capensis sp. nov.

- Scutum finely punctate and at least on disc between punctures smooth and shiny (Fig. 13B); S6 S8 and genitalia as in Fig. 13D-H R. simulans Michener, 1981

3. Metasomal terga finely shagreened and dull (Fig. 11C); prepygidial and pygidial fimbria yellowish brown (Fig. 11C); S6 - S8 and genitalia as in Fig. 11D-H ................ R. namaquaensis sp. nov.

- Metasomal terga between punctures smooth and shiny at least on T1 - T2 (Figs 8C, 16C); prepygidial and pygidial fimbria brown to black (Figs 8C, 16C); S6 - S8 and genitalia different ........ 4

4. Metasomal terga with oily bluish shine; S6 - S8 and genitalia as in Fig. 16D-H

R. variabilis sp. nov.

- Metasomal terga without oily bluish shine; S6 - S8 and genitalia as in Fig. 8D-H

R. karooensis sp. nov.

\section{Discussion}

\section{Redefinition of the genus Redivivoides}

Within the Melittinae Michez et al. (2009), based on a phylogenetic study, recognize two tribes; the Macropidini comprises genera with two submarginal cells (Afrodasypoda, Macropis, Promelitta and the fossil taxa Eomacropis and Paleomacropis) and the Melittini, comprising genera with three submarginal cells (Melitta, Rediviva, Redivivoides). In the Melittini Melitta is characterized by a well-defined, large and dull propodeal triangle (except Melitta schultzei; Michez \& Eardley 2007) while in Rediviva and Redivivoides this is ill-defined, small and shiny, although in some species superficially sculptured.

In both Macropis (Fig. 1A-B) and Rediviva (Fig. 1C-D) the females can easily be recognized by their broadened hind tibia and basitarsus with the scopa consisting of densely plumose, velvety pubescence for transporting floral oil, while the elongate fore tarsi (extreme in some species) are a synapomorphy of Rediviva (Michener 1981, 2007). In contrast the females of Redivivoides have short front legs with simple hairs and a slender hind tibia, as in Melitta (Michener 1981). The scopa consists of sparse simple bristles (more dense and usually with at least a few shortly branched hairs in Melitta; Fig. 1G) with the anterior margin of the scopa shining, unlike in other genera (Fig. 1E) (Michener 1981). The hind basitasus of Redivivoides females is slightly broadened, about 2-2.5 times as long as its maximum width with the posterior margin curved and without an apical process (Fig. 1F) while in Melitta it is slender, three or more times as long as broad, parallel-sided and with a small apical process (Fig. 1H) (Michener 1981). In Redivivoides a penicillus is generally missing while it is present in all Melitta species known to me and modified into a brush-like structure used for lining the wall of brood cells in Rediviva and Macropis (Schäffler \& Dötterl 2011).

As in females, male Melitta can be recognized by the large and dull propodeal triangle (except Melitta schultzei) (ill-defined, small and shiny in Rediviva and Redivivoides), S7 having a large plate that is truncate or emarginate apically (sometimes with hair patches at posterior lateral angles) and with lobes 
or processes reduced to small sclerotic structures like in Melitta budensis (Michez \& Eardley 2007). In Rediviva and Redivivoides S7 in turn has a small disc with the apex bifid and/or with membranous lobes and the gonostyli are relatively long (Michener 1981, 2007).

The differentiation of Rediviva and Redivivoides males is problematic. Michener $(1981,2007)$ suggested that the broad, subtrunctate apex of the male S7, with its large laterally attached, vertical, membranous hairy lobes (Fig. 13E) is a unique apomorphy of Redivivoides. However, these characters seem to be species specific for $R$. simulans and they are either absent (R. karooensis, $R$. namaquaensis) (Figs 8E, $11 \mathrm{E}$ ) or reduced ( $R$. capensis, $R$. variabilis) (Figs 3E, 16E) in the other four species (the males of $R$. eardleyi and $R$. kamieskroonensis are unknown). Michener (1981) mentioned the weak pygidial plate in male $R$. simulans as a character differentiating Redivivoides from both Melitta and Rediviva. A pygidial plate is also present in male Macropis and in $R$. variabilis, where it is reduced to a narrow longitudinal, slightly elevated and shiny ridge but it is missing in all the other three species making it unsuitable as a differentiating character.

Generally, the morphology of S7, S8 and the genitalia of Redivivoides males (Figs 3, 8, 11, 13, 16) reflect much of the morphological diversity known from the much more species-rich Rediviva as illustrated in Whitehead \& Steiner (2001) and Whitehead et al. (2008). Although well characterized as species, the obvious lack of apomorphic characters defining the males of Redivivoides at the genus level make their identification difficult and indicate the close relationship of both genera as suggested by Michener (1981) and Michez et al. (2009).

\section{Origin of oil-collecting}

The origin of oil-collecting in bees has been much debated and this behaviour has evolved independently at least five times in the Centridini, Ctenoplectrini, Exomalopsini, Tetrapediini and Melittinae (Buchmann 1987; Vogel 1974, 1986, 1990; Renner \& Schaefer 2010). Within the Melittinae floral oil is collected by bees of the genera Macropis and Rediviva (Michener 2007). Melittids are the most basal bees (Danforth et al. 2006) and, thus, they can be a key-group for understanding the evolution of oil-collecting in bees in general. Michener (1981) and later Michez et al. (2009), based on the results of a phylogenetic study, discussed whether oil-collecting has evolved only once in melittids or if there are two independent origins in Macropis and Rediviva.

In both scenarios the phylogenetic position of Redivivoides is crucial to understanding the evolutionary history of early bees. In Michez et al.'s (2009) analysis Redivivoides arose from Rediviva, making the latter paraphyletic, indicating a loss of oil-collecting in Redivivoides. However, only two of the currently 24 described Rediviva species and only $R$. simulans of the now seven known Redivivoides species were included in the study. A broader approach including more species is required to confirm the paraphyly of Rediviva.

If Redivivoides evolved from Rediviva the question is why Redivivoides is only present in the winter rainfall region in the west of South Africa whereas Rediviva also occurs in the summer rainfall area in the east of the country. Either Redivivoides evolved in the winter rainfall region and has not spread to the east of South Africa or it became extinct there. An interesting parallel case is the 11 of 35 described species of the Colletes fasciatus-group in western South Africa that have a reduced scopa, which is unique in the genus (Kuhlmann 2006, 2007).

Based on the present taxonomic revision there is now additional evidence that Redivivoides species might have lost their oil-collecting structures, as presumably happened in some Neotropical Centris species (Michener 2007). With the exception of Redivivoides all non oil-collecting genera of the Melittinae have a slender hind basitarsus and a dense scopa with at least some branched long hairs. In contrast, the 
hind tibia and basitarsus of oil-collecting Macropis and Rediviva is very broad and the scopa consists of densely plumose, short pilosity for oil-collecting embedded in a matrix of sparse, long, simple, emergent hairs (Fig. 1A-D) (Michener 1981), with the latter reminiscent of Redivivoides (Fig. 1E-F). Thus, the broadened and posteriorly curved hind basitarsus lacking an apical process (present in Melitta, Macropis and in modified form in some Rediviva), the sparse scopa consisting of only simple hairs in Redivivoides and the lack of a penicillus (present in Melitta and modified into a brush-like structure in Rediviva and Macropis) might be remnants indicating a loss of oil-collecting structures. This view is supported by the phylogenetic position of $R$. simulans, arising from Rediviva, rendering Rediviva paraphyletic (Michez et al. 2009), the similar structure of male genitalia, S7 and S8 and a study of fore and mid leg anatomy by Steiner \& Cruz (2006) suggesting that Redivivoides has descended from an oil-collecting ancestor.

The close relationship of Redivivoides and Rediviva is also reflected in flower visitation. Most Rediviva collect floral oil on Scrophulariaceae (Whitehead \& Steiner 2001; Whitehead et al. 2008) and pollen from this plant family is also a major constituent of female scopal pollen loads (Kuhlmann unpubl.) but it is rarely used by other Melittidae (Michez et al. 2008). Whilst no information is available on flower visitation of $R$. eardley $i \mathrm{sp}$. nov. and $R$. kamieskroonensis sp. nov. and only a single observation for $R$. capensis sp. nov. all the other Redivivoides species were found visiting Scrophulariaceae with $R$. karooensis sp. nov. and $R$. namaquaensis sp. nov. obviously having a preference for this family. Although Kuhlmann \& Eardley (2012) showed that Scrophulariaceae are visited and their pollen collected by a range of bee species it is usually only a minor component in scopal pollen loads (Kuhlmann unpubl.). Thus, the shared preference for Scrophulariaceae even though only based on a small number of observations can be seen as another indicator for the common ancestry of both genera.

However, a robust phylogeny including more species of Rediviva and Redivivoides is required to better understand the evolution of oil-collecting and phylogeography of both genera.

\section{Acknowledgements}

I am very much indebted to the following colleagues (in alphabetical order of collection acronyms) who made specimens under their curation available for this study: S.K. Gess and F.W. Gess (AMGS), B.N. Danforth (CUIC), T. Griswold (EMUS), L. Packer (LPCT), D. Larsen and S. van Noort (SAMC) and C.D. Eardley (SANC). Northern Cape Nature Conservation Service and the Western Cape Nature Conservation Board (CapeNature) are gratefully acknowledged for giving their permission to collect bees. Gavin Broad, London, kindly made linguistic corrections. The insightful comments of two anonymous reviewers helped to improve the paper.

\section{References}

Arnett R.H., Samuelson G.A. \& Nishida G.M. 1993. The Insect and Spider Collections of the World. Flora \& Fauna Handbook, 11 (2nd Edition), Sandhill Crane Press, Gainesville.

Buchmann S.L. 1987. The ecology of oil flowers and their bees. Annual Review of Ecology and Systematics 18: 343-369.

Danforth B.N., Sipes S., Fang J. \& Brady S.G. 2006. The history of early bee diversification based on five genes plus morphology. Proceedings of the National Academy of Sciences 103 (41): 15118-15123. http://dx.doi.org/10.1073/pnas.0604033103

Germishuizen G. \& Meyer N.L. (eds.) 2003. Plants of southern Africa: an annotated checklist. Strelitzia, 14, National Botanical Institute, Pretoria. 
Kuhlmann M. 2006. Scopa reduction and pollen collecting of bees of the Colletes fasciatus-group in the winter rainfall area of South Africa (Hymenoptera: Colletidae). Journal of the Kansas Entomological Society 79: 165-175. http://dx.doi.org/10.2317/0505.10.1

Kuhlmann M. 2007. Revision of the bees of the Colletes fasciatus-group in southern Africa (Hymenoptera: Colletidae). African Invertebrates 48: 121-165.

Kuhlmann M. 2009. Patterns of diversity, endemism and distribution of bees (Insecta: Hymenoptera: Anthophila) in southern Africa. South African Journal of Botany 75: 726-738. http://dx.doi.org/10.1016/j. sajb.2009.06.016

Kuhlmann M. \& Eardley C.D. 2012. Pollen resources of non-Apis bees in southern Africa. In: Patiny S. (ed.) Evolution of Plant-Pollinator Relationships: 439-456. Cambridge University Press, Cambridge.

Michener C.D. 1981. Classification of the bee family Melittidae with a review of species of Meganomiinae. Contributions of the American Entomological Institute 18: 1-135.

Michener C.D. 2007. The Bees of the World. $2^{\text {nd }}$ edition, Johns Hopkins University Press, Baltimore, Maryland.

Michez D. \& Eardley C.D. 2007. Monographic revision of the bee genus Melitta Kirby 1802 (Hymenoptera: Apoidea: Melittidae). Annales de la Société Entomologique de France (n.s.) 43: 379440.

Michez D., Patiny S. \& Danforth B.N. 2009. Phylogeny of the bee family Melittidae (Hymenoptera: Anthophila) based on combined molecular and morphological data. Systematic Entomology 34 (3): 574 597. http://dx.doi.org/10.1111/j.1365-3113.2009.00479.x

Michez D., Patiny S., Rasmont P., Timmermann K. \& Vereecken N.J. 2008. Phylogeny and host-plant evolution in Melittidae s.l. (Hymenoptera: Apoidea). Apidologie 39: 146-162. http://dx.doi.org/10.1051/ apido: 2007048

Pauw A. 2006. Floral syndromes accurately predict pollination by a specialized oil-collecting bee (Rediviva peringueyi, Melittidae) in a guild of South African orchids (Coryciinae). American Journal of Botany 93: 917-926.

Renner S.S. \& Schaefer H. 2010. The evolution and loss of oil-offering flowers: new insights from dated phylogenies for angiosperms and bees. Philosophical Transactions of the Royal Society B 365: 423-435.

Schäffler I. \& Dötterl S. 2011. A day in the life of an oil bee: phenology, nesting, and foraging behavior. Apidologie 42: 409-424. http://dx.doi.org/10.1007/s13592-011-0010-3

Steiner K.E. \& Cruz B. 2006. The evolution of oil collection and oil collecting structures in the Melittidae: Abstract. Symposium 4: Phylogeny and Evolution of Bees: A Tribute to Charles Michener. International Union for the Study of Social Insects, Washington, DC, 31 July 2006.

Steiner K.E. \& Whitehead V.B. 1990. Pollinator adaptation to oil-secreting flowers - Rediviva and Diascia. Evolution 44: 1701-1707.

Steiner K.E. \& Whitehead V.B. 1991. Oil flowers and oil bees: further evidence for pollinator adaptation. Evolution 45: 1493-1501.

Vogel S. 1974. Ölblumen und ölsammelnde Bienen. Tropische und Subtropische Pflanzenwelt 7: 1-267.

Vogel S. 1986. Ölblumen und ölsammelnde Bienen. Zweite Folge. Lysimachia und Macropis. Tropische und Subtropische Pflanzenwelt 54: 1-168.

Vogel S. 1990. Ölblumen und ölsammelnde Bienen. Dritte Folge. Momordica, Thladiantha und die Ctenoplectridae. Tropische und Subtropische Pflanzenwelt 73: 1-186. 
Whitehead V.B. \& Steiner K.E. 2001. Oil-collecting bees of the winter rainfall area of South Africa (Melittidae, Rediviva). Annals of the South African Museum 108: 143-277.

Whitehead V.B., Steiner K.E. \& Eardley C.D. 2008. Oil collecting bees mostly of the summer rainfall area of southern Africa (Hymenoptera: Melittidae: Rediviva). Journal of the Kansas Entomological Society 81: 122-141. http://dx.doi.org/10.2317/JKES-703.12.1

Manuscript received: 30 July 2012

Manuscript accepted: 7 December 2012

Published on: 19 December 2012

Topic editor: Koen Martens

Printed versions of all papers are also deposited in the libraries of the institutes that are members of the EJT consortium: Muséum National d'Histoire Naturelle, Paris, France; National Botanic Garden of Belgium, Meise, Belgium; Royal Museum for Central Africa, Tervuren, Belgium; Natural History Museum, London, United Kingdom; Royal Belgian Institute of Natural Sciences, Brussels, Belgium; Natural History Museum of Denmark, Copenhagen, Denmark. 